\title{
Valor Maravilha: Metamorfoses da Acumulação Capitalista no Espaço Portuário do Rio de Janeiro
}

\author{
Guilherme Leite Gonçalves ${ }^{1}$ \\ Sérgio Costa ${ }^{2}$
}

${ }_{1}$ Professor Adjunto de Sociologia do Direito na Universidade do Estado do Rio de Janeiro (UERJ).

Rio de Janeiro, RJ. Brasil.

E-mail: guilherme.leite@uerj.br; https://orcid.org/0000-0003-4906-477X

${ }^{2}$ Pesquisador do Centro Brasileiro de Análise e Planejamento (Cebrap) e Diretor do Instituto de Estudos

Latino-Americanos da Freie Universität. Berlim, Alemanha.

E-mail: sergio.costa@fu-berlin.de; https:// orcid.org/0000-0001-6347-0614

\section{INTRODUÇÃO}

Triunfante, o então prefeito do Rio de Janeiro, Eduardo Paes, anun1 cia, na edição de número 18 da revista Porto Maravilha, os avanços do projeto de "revitalização" e "requalificação" da área de cerca de 5 milhões de $\mathrm{m}^{2}$ na zona portuária da cidade. Para o prefeito, seguindo o tom geral adotado na divulgação do amplo plano de intervenção urbana desencadeado em 2009, o projeto Porto Maravilha "recupera" para o uso público "área central da cidade, com imensa importância histórica" e que havia se tornado "um vazio demográfico", depois de “décadas de degradação da Região Portuária" (Paes, 2015:2).

Os moradores locais, as várias organizações civis que vêm acompanhando, criticamente, o empreendimento bem como as pesquisas acadêmicas já disponíveis sobre o tema, mesmo quando apoiam o projeto, são unânimes em rejeitar a ideia de que a área em questão é um vazio de vida e sociabilidade. Ressaltam, ao contrário, não só a presença dos moradores como também variadas atividades culturais que já há muito se instalaram e se desenvolvem naquela região.

Em consonância com a bibliografia recente que recupera e amplia a noção de acumulação primitiva desenvolvida por Marx, o presente artigo defende que a criação retórica de um vazio demográfico na região central do Rio de Janeiro é parte do processo que define a fronteira 
entre territórios capitalistas e não capitalistas, condição para a produção de valor, no sentido capitalista. O objetivo do texto é, no entanto, mais amplo: mostrar que os processos de incorporação e desacoplamento da região portuária, da dinâmica de acumulação, acompanham a história daquele espaço, desde a criação do porto no final do século XVI.

Na primeira parte, reconstruímos, de maneira sumária, os desenvolvimentos mais recentes na teoria marxista da expansão capitalista, os quais indicam que mecanismos de acumulação primitiva continuam sendo centrais para a reprodução do capitalismo. A partir do conceito de acumulação entrelaçada buscamos articular e expandir tais desenvolvimentos teóricos. A segunda parte retoma diferentes fases da história da zona portuária do Rio de Janeiro, de sorte a indicar os movimentos mais importantes no padrão de acumulação ali observado. Em sua terceira parte, aprofundamos a discussão das variações do padrão de acumulação observado em épocas específicas. De sorte a delimitar minimamente o vasto material relevante para a análise aqui desenvolvida, estabelece-se como marco orientador mudanças na legislação cruciais para viabilizar os padrões de acumulação verificados em cada período. Por fim, a seção conclusiva sintetiza os vínculos entre os desenvolvimentos teóricos e o caso estudado, e indica as questões que permanecem em aberto como uma possível agenda para pesquisas futuras.

\section{DA ACUMULAÇÃO PRIMITIVA À ACUMULAÇÃO ENTRELAÇADA: DESENVOLVIMENTOS DA TEORIA MARXISTA DA EXPANSÃO CAPITALISTA}

Tanto a teoria da regulação (Boyer e Saillard, 2005), quanto a teoria das crises (Harvey, 2005) identificam como motor da acumulação a necessidade de o capitalismo produzir condições materiais durante certo período, capazes de garantir sua expansão e com isso assegurar sua conservação como modo de produção. $\mathrm{O}$ capitalismo é assim uma formação dinâmica que depende da pressão constante por crescimento e da superação contínua de autolimitações produzidas no movimento permanente do capital. Trata-se, em resumo, de uma engrenagem sensível a quaisquer limites de autoexpansão, os quais, quando atingidos, acionam processos que a levam a mudar de pele com o fim de gerar um novo ciclo de estabilidade (Dörre, 2012:41).

Para compreender esse processo é necessário reconstruir brevemente o conceito de acumulação primitiva do capital, no âmbito da economia política marxista. 
Percurso conceitual da noção de acumulação primitiva

Em Marx (2013:741), a acumulação primitiva é tratada como um ato originário que permite observar o movimento do capital não como um círculo vicioso em que dinheiro é transformado em capital e que, por meio desse, se faz mais-valia e vice-versa. Ao contrário, o autor mostra que existe uma acumulação prévia que é o ponto de partida para o desenvolvimento do modo de produção capitalista. Como o pressuposto para a produção capitalista é a transformação de bens materiais ou imateriais em valor e isto só é possível pelo "divórcio entre os trabalhadores e a propriedade das condições de desenvolvimento do trabalho", Marx (ibid.:742) ${ }^{1}$ conclui que a acumulação primitiva é o "processo histórico de separação entre o produtor e os meios de produção". Trata-se, portanto, de um ato de expropriação de grupos sociais, cuja consequência é a criação de uma massa livre forçada a vender sua força de trabalho. Para Marx, esse ato envolve conquistas imperiais, colonizações, roubo e regulação jurídica, isto é, "violência diretamente não econômica".

A acumulação primitiva é, portanto, um ato de expropriação em dois níveis. Nos espaços da Europa, onde o capitalismo industrial surgiu originalmente, os produtores diretos foram privados dos meios de garantir sua própria reprodução física e social. De mãos dadas com essa separação, a expansão capitalista foi alimentada pela violência do colonialismo e concentração do capital mercantil. Para Marx (ibid.:786) ambos os mecanismos fazem parte de um processo global de acumulação. Quando, todavia, tal processo já está estabelecido, Marx (ibid.:834) afirma que a expropriação não cessa, mas é reproduzida em uma escala cada vez maior, de acordo com formas específicas de centralização de capitais e propriedades privadas.

Rosa Luxemburgo mostra de maneira mais explícita como a acumulação primitiva é fator determinante da dinâmica do desenvolvimento do capitalismo em toda sua existência. Para ela, uma parte do movimento da acumulação se realiza a partir de um processo puramente econômico entre capitalistas e trabalhadores nos espaços de produção da mais-valia (Luxemburgo, 1975:315). Nesse âmbito, conforme suas palavras: "domina a paz, a propriedade e a igualdade como formas", isto é, "a apropriação da propriedade alheia transforma-se em direito de propriedade; a exploração, em troca de mercadorias; e a dominação de classes, em igualdade" (:397). Todavia, como apenas 
uma parte relativa e limitada da mais-valia consegue ser apropriada neste trânsito interno, isto é, no local de sua produção, Luxemburgo (:315-316) sustenta que o sistema sempre necessita recorrer a um "fora" não capitalista para realizá-la por completo. Essa outra dimensão da acumulação opera no cenário mundial e não se verifica por meio das formas sociais da dissimulação. Ao contrário, no fluxo entre o capital e os espaços não capitalistas, a autora afirma que os métodos empregados recorrem permanentemente à violência explícita como "a política colonial, o sistema de empréstimos internacionais, a política de interesses privados e a guerra" (:397-398).

A partir das considerações de Luxemburgo, Harvey (2009:74) desenvolve o argumento segundo o qual a acumulação baseada na violência não é uma "etapa originária" ou um ato passado, mas um processo que se repete permanentemente no curso do capitalismo. Por essa razão, ele passou a denominá-lo de "acumulação por despossessão" Harvey (2009:64) sustenta que "a sobreacumulação em um sistema territorial específico" é resultado tanto do excedente de trabalho (desemprego) como do capital (abundância de mercadorias que não podem ser vendidas sem perdas, inutilização da potencialidade produtiva e excesso de capital desprovido de capacidade de se tornar rentável). Segundo o autor, tal excedente pode ser absorvido por ajustes temporal-espaciais. Quando esses ajustes temporal-espaciais não se dão através da "reprodução ampliada sobre uma base sustentável", Harvey (2009:63-64) afirma que a acumulação passa a recorrer a outros meios, qual seja, a acumulação por despossessão. Nesse momento, conclui o autor, ela recorre a um "capitalismo de rapina" que retoma as práticas predatórias e a violência política do ato original (ibid.:72). $\mathrm{O}$ fator decisivo, nesse processo, é que a acumulação do capital sempre se dá por meio de diferentes formas de intervenções estatais.

Esse é o ponto de partida para os estudos de Dörre que, nos últimos anos, se dedicou a oferecer um teorema da Landnahme ${ }^{2}$ capitalista. Sua premissa é a de que o capitalismo é "uma economia de mercado que se autonega continuamente" (Dörre, 2012:30). Para o autor, o pensamento econômico-liberal, baseado na ideia de concorrência e eficiência como ausência de coação e regulação, mascara tanto a dinâmica capitalista quanto a dimensão político-estatal de seu próprio projeto. Se é verdade que o liberalismo ortodoxo contesta a ideia do Estado como fórum que determina as regras do jogo e como árbitro que vela por sua aplicação, também é certo que os atores de merca- 
do operam com base em mecanismos de cooperação e dependem do direito como meio de calculabilidade para se desenvolver. Por essa razão, Dörre sustenta que a tese da economia pura de mercado desempenha função ideológica, pois oculta as relações de poder e de política que permeiam as relações de troca (ibid.:30). A partir dessa crítica, conclui que a intervenção político-regulatória é uma constante no desenvolvimento do capitalismo.

Na esteira de Harvey, o modelo da Landnahme entende que a acumulação capitalista sempre esbarra em barreiras temporal-espaciais que precisam ser superadas para sua continuidade. A ideia de impossibilidade de realização completa da mais-valia em seu lugar de produção é retomada para demonstrar que a acumulação do capital exige, para sua perpetuação, novos territórios não capitalistas que "poderão prover novos recursos, matérias-primas e mercados de trabalho" (ibid.:40). Dörre assume o argumento de Harvey segundo o qual os espaços não capitalistas não se resumem a territórios ou modos de produção já existentes, o que tornaria o processo de expansão do capital um fenômeno irreversível, que tenderia a um fim. Ao contrário, a necessidade permanente de superar as fronteiras da acumulação leva o capitalismo a produzir espaços não capitalistas, que ele, posteriormente, expropriará. Com isso, indica o autor: "a cadeia de Landanahme torna-se, em princípio, infinita" (:42).

A partir dessa consideração, o autor amplia a tese de Harvey sobre o desenvolvimento capitalista. Trata-se da acumulação do capital pela Landnahme de espaços não capitalistas existentes ou produzidos ativamente. Dessa tese, Dörre deduz que o capitalismo funciona com base em uma dialética dentro-fora, segundo a qual os limites de sua capacidade interna de acumulação exigem a espoliação de um "fora". Essa equação, no entanto, só se fecha por meio de intervenções político-regulatórias. De acordo com o autor, a tomada capitalista do "fora" é um processo que se baseia necessariamente nesse tipo de intervenção.

Dörre (2012:38) especifica esse argumento ao mostrar que a violência política se encontra na "forma da precariedade produzida politicamente" capaz "de disciplinar a força de trabalho livre para atividades" no novo espaço, que é incorporado à lógica da acumulação. A questão que se coloca então é: quais as relações entre o direito e essa "forma da precariedade produzida politicamente"? 
0 papel do direito na acumulação primitiva (permanente): leis punitivas e parcerias público-privadas

Para responder à pergunta anterior no âmbito da economia política marxista é necessário voltar a Marx. Quando apresentou sua análise sobre a acumulação primitiva do capital, Marx elaborou um quadro bastante complexo de diferentes e contraditórios usos do direito. Não é o caso de reconstruir todo esse quadro no presente ensaio. Para nosso argumento, o que chama a atenção, no entanto, é o destaque que o autor atribuiu ao direito penal. Quando tratou da usurpação violenta da propriedade comum na Inglaterra, Marx identificou duas fases histórico-jurídicas distintas no que se refere à regulação dos direitos à terra. A primeira se refere ao período que compreende do final do século $\mathrm{XV}$ ao século $\mathrm{XVII}$, quando a respectiva usurpação foi praticada ilegalmente e contra legislações que buscavam freá-la. A segunda fase verificou-se a partir do século XVIII, momento em que a usurpação passou a ser legal e a própria lei se tornou "o veículo do roubo" (Marx, 2013:709).

Ambos os momentos, no entanto, foram atravessados pelo direito penal, que Marx então denominou de "legislação sanguinária". Essas leis operavam paralelamente à expropriação dos camponeses de suas terras. À medida que eram expulsos, eles se tornavam completamente livres para vender sua força de trabalho ao capitalista, mas não conseguiam ser automaticamente absorvidos pela economia industrial. De um lado, as manufaturas não cresciam na mesma proporção do número elevado de camponeses expropriados; de outro, esses camponeses, socializados em outras práticas, não correspondiam aos novos padrões de trabalho e modos de vida exigidos. Formava-se, assim, uma massa ainda não economicamente absorvida que necessitava ser "ajustada à disciplinada nova situação" (ibid.:762). É, dessa perspectiva, que Marx explicou o surgimento na Inglaterra e na França de diversas leis sanguinárias contra a vagabundagem e a pauperização desde o século XV. O direito penal, nesse sentido, cumpriu um papel de disciplinamento da força de trabalho durante o processo de acumulação primitiva.

Nos recentes debates, Harvey indica outros instrumentos jurídicos que participam da acumulação por despossessão. Eles estão relacionados com o papel do direito no atual regime de acumulação financeira. 
Essa análise depende, no entanto, de uma clareza do funcionamento dos processos de Landnahme capitalista na prática. Harvey (2005:147) mostra que o fordismo construiu, por meio de investimentos em infraestrutura e força de trabalho, condições para a exploração econômica em um determinado espaço. Tal exploração foi "amortizada apenas a longo prazo" (Dörre, 2012:42-43). Nesse ciclo, o Estado tornou-se peça-chave para os movimentos do capital e, ao absorver a produção por meio de investimentos em bens públicos, criou uma estratégia de desarme do dispositivo da sobreacumulação.

Dörre interpreta esse processo como a formação de um "fora" que, apesar de utilizado para melhorar a prestação econômica, "é inacessível para a acumulação privada" Dörre (2012:43). Com isso, foram construídas as condições para uma nova Landnahme capitalista. Quando esse espaço público esgotou seu potencial de amortização e, consequentemente, tornou-se um obstáculo para a valorização do capital, passou a ser tomado pelo capital privado ${ }^{3}$. Com essa Landnahme capitalista do público, o capital excedente pode agora ser convertido em ativo. Isso só é possível, no entanto, porque, nos termos de Marx, as relações de propriedade mudaram e, consequentemente, os então produtores de serviços públicos foram separados dos meios de produção públicos ou comuns. Isso, no entanto, levou à desindustrialização e à precarização, isto é, a um novo "fora" a ser posteriormente tomado por outro tipo de Landnahme capitalista, qual seja, o capitalismo financeiro (Dörre:44).

Caracterizado pelas políticas neoliberais de austeridade e por uma orientação ao mercado global, todas essas ações orientadas para privatizar o mercado de bens e serviços até então produzidos pelo Estado foram desenvolvidas por meio de intervenções regulatórias e reformas legais. Tais mecanismos jurídico-políticos viabilizaram a expropriação pela via das privatizações e, ao mesmo tempo, a constituição de uma massa de precarizados pela modificação das legislações trabalhistas (ampliação da terceirização da mão de obra, "flexibilização" dos contratos de trabalho temporários, etc.) (ibid.:63-68). Se os elevados índices de encarceramento em suas diversas formas demonstram, na linha desenvolvida por Marx, a manutenção do papel do direito penal como estratégia de disciplinamento da força de trabalho no processo de acumulação, Harvey aponta para o fato de que as ações de mercantilização e financeirização dos bens públicos dependeram de um novo desenho institucional: as parcerias público-privadas (Harvey, 1989:7). 
Tais parcerias são consideradas a característica central do novo modelo social de empresariamento. Para Harvey, elas foram capazes de remodelar as condições de acumulação previamente existentes e que haviam se transformado em barreiras para a expansão capitalista (ibid.:7-9). Durante o fordismo, o modelo de gerenciamento baseava-se no repasse de recursos e no envolvimento direto de atores públicos com atividades produtivas e de investimentos. As transformações macro pós-1973 construíram, todavia, um novo ambiente econômico que passou a ser dependente da negociação direta do mercado financeiro e da reconstrução de uma paisagem física e social que viabilizasse a competição por recursos e empregos. Dessa perspectiva, Harvey apresenta a ideia de que as cidades passaram a assumir um comportamento empresarial. Tal empresariamento tornou-se possível pelas parcerias público-privadas, quais sejam, contratos entre a administração pública e grupos privados, nos quais esses últimos fornecem, por meio de contraprestação remunerada, infraestruturas, serviços e equipamentos urbanos.

A partir do objetivo de transformação da paisagem de modo a orientá-la ao mercado, as parcerias público-privadas se converteram no instrumento jurídico de interesse espacial no âmbito da acumulação capitalista financeirizada. Ou seja, parcerias público-privadas emergem como instrumentos jurídicos essenciais para as espoliações, esbulhos e usurpações, que reajustam temporal e espacialmente as condições necessárias à acumulação do capital. Se, nos fenômenos de espoliação observados por Marx, o direito penal exercia o papel central no sentido de facultar a separação entre produtores e meios de produção, a transformação das cidades como espaço da acumulação depende agora também de reconfiguração de outras esferas do direito para se concretizar. Além do direito civil e da legislação específica sobre parcerias público-privadas, a adequação do direito urbanístico e das leis de uso e ocupação do solo, redefinindo condutas e formas usualmente aceitas e puníveis em cada zona, ocupa também lugar de relevância.

É óbvio que a generalização do papel das parcerias público-privadas para regimes não financeirizados poderia incorrer em evidente risco de anacronismo, o que vedaria qualquer comparação de relações jurídicas anteriores com categorias contemporâneas do direito econômico e administrativo. Todavia, se pensarmos que as parcerias público-privadas indicam o entrelaçamento entre atores públicos e privados, voltado para a criação de espaço adequado à circulação e acumulação do 
capital, então nesse sentido lato torna-se possível empregar essa noção para compreender outras fases históricas de desenvolvimento do capitalismo, como veremos a seguir no estudo do Porto do Rio de Janeiro.

\section{Acumulação entrelaçada}

Ao lado do papel do direito, outro aspecto importante dos processos contemporâneos de Landnahme, que pode ser retomado em um exame histórico e que não havia sido ainda adequadamente explorado nos trabalhos de Harvey e Dörre, é sua dimensão linguístico-discursiva, como mostra o estudo recente de Backhouse (2015). Ao estudar a chamada Landnahme verde, possibilitada pela introdução de legislação de proteção ambiental no estado do Pará, a autora mostra que a construção da figura retórica "terras degradadas" - quais sejam, remanescentes de desmatamento - foi fundamental para transferir a propriedade fundiária de pequenos produtores rurais para grandes empresas como a Vale. Na medida em que dispõem dos recursos técnicos e materiais para atender a todos os requisitos estabelecidos pelo programa de incentivo à recuperação de "terras degradadas" promovido na região, estas empresas adquirem vantagens comparativas para cultivar a respectiva área. Vão, assim, incorporando paulatinamente a seus domínios as terras "degradadas" antes ocupadas por posseiros e pequenos proprietários.

Os diferentes desenvolvimentos do conceito marxista de acumulação primitiva reconstruídos brevemente acima, na medida em que focalizam momentos e processos distintos no âmbito da expansão capitalista, podem ser fundidos numa categoria mais abrangente, a qual denominamos acumulação entrelaçada. A expressão é inspirada pela ideia de modernidade entrelaçada, cunhada por Conrad e Randeria (2002), ao mostrar que, apesar de ser representada de forma separada e isolada nas historiografias nacionais, a modernidade é, desde sua origem, global, pois vincula e entrelaça as diferentes regiões do mundo.

Similarmente, a acumulação capitalista entrelaçada leva à interconexão e interpenetração não só das diferentes regiões do mundo, mas também de outras dimensões da expansão capitalista. De forma sistemática, ainda que não exaustiva, podem ser identificados ao menos quatro níveis de interpenetração inerentes à acumulação entrelaçada: 
1. A incorporação de novos espaços não capitalistas ao processo de acumulação - por mais locais que tais espaços possam parecer - refletem sempre dinâmicas globais, caracterizando o que Luxemburgo (1975:300-302) qualificava como desaparecimento do local;

2. Os distintos padrões históricos de acumulação (acumulação primitiva, acumulação por despossessão, Landnahme financeira) não têm uma cronologia fixa nem são exclusivos. Essas diferentes formas podem coexistir numa mesma época e num mesmo espaço geográfico;

3. Decorre do anterior, que distintos mecanismos associados à acumulação capitalista, incluindo-se a mobilização do direito, do estado e da política, da cultura bem como a produção discursiva nos termos elucidados por Backhouse (2015), também coexistem espacialmente e temporalmente;

4. O avanço da acumulação funde, de modo irremediável, as categorizações sociais relativas à classe, gênero, etnicidade e raça, de sorte que as assimetrias socioeconômicas e de poder que vão se amalgamando ao longo da história do capitalismo são cada vez mais desigualdades entrelaçadas, no âmbito das quais categorizações sociais se interpenetram (Jelin, Motta e Costa, 2018). Esse aspecto, por razões de espaço, só poderá ser explorado muito marginalmente no presente artigo.

\section{O PORTO, A CAPITAL E O CAPITAL: PANORAMA HISTÓRICO}

Como visto até aqui, a acumulação entrelaçada não se baseia apenas na tomada de ambientes não capitalistas preexistentes, o que implicaria seu esgotamento, uma vez completada a expansão geográfica do capitalismo por todo o globo. Trata-se mais propriamente da capacidade permanente de produção de novos espaços capitalistas, sempre que a acumulação se depara com uma barreira para sua expansão (Harvey, 1975:18). Por tal produção de novos espaços capitalistas deve-se entender também a reconfiguração completa das características físicas, legais e sociais do ambiente já ocupado em função de variações nos tipos de tecnologia, capital e força de trabalho empregados. Nesse âmbito, as relações, formas e padrões anteriores de produção, 
consumo, regulação, cultura e vida são modificados por diversos fenômenos como novas edificações, desenhos urbanos, fluxos migratórios, regras de organização e controle, que podem manter ou introduzir assimetrias e descontinuidades socioespaciais (Harvey, 1985).

Ao discutir a acumulação capitalista entrelaçada na região portuária do Rio de Janeiro é preciso distinguir inicialmente três formas diferentes de inserção do porto na dinâmica da acumulação. A primeira diz respeito ao porto em suas funções-fim, ou seja, permitir a entrada e saída de mercadorias e pessoas na cidade e no país. Esse fluxo de bens assegura a integração brasileira, desde a época colonial, à dinâmica da acumulação global. A segunda forma de acumulação se dá no espaço do porto mesmo. Trata-se aqui de sua atividade-meio, qual seja, a geração de valor através de serviços ali prestados no embarque, desembarque e armazenamento de mercadorias. A terceira forma diz respeito à interação entre o porto, suas adjacências e o conjunto da cidade. No âmbito dessa trama de relações, a ocupação e construção do próprio espaço físico da zona portuária se inserem nas dinâmicas dentro-fora-dentro da acumulação capitalista. Esses três modos de integração da área portuária à dinâmica da acumulação variam ao longo do tempo, variando com eles as formas de incorporação de espaços não capitalistas dominantes em cada época.

Historicamente, a primeira função exercida pelo porto foi a de integrar o Brasil como colônia portuguesa à economia global. De algum modo, o porto funcionava como o elo que ligava o espaço da acumulação primitiva ao advento do capitalismo. Isto é, o porto se origina dos interesses do colonizador português que, em razão da geografia da Baía da Guanabara, a escolheu como principal escoadouro do pau-brasil, do açúcar e mais tarde, sobretudo a partir da criação do chamado Caminho Novo, nas primeiras décadas do século XVII, do ouro saqueado de Minas Gerais. O porto era igualmente importante como entreposto no comércio de bens e pessoas escravizadas ${ }^{4} \mathrm{e}$ desempenhava também função-chave como interligação ao Porto de Buenos Aires, inscrevendo-se, assim, nas rotas comerciais que vinculavam os domínios coloniais espanhóis e portugueses nas Américas, a Europa e a África (Figueiredo, 2005:24-25) .

A crescente importância do Rio de Janeiro e de seu porto na geopolítica colonial leva a que, a partir de 1763, o Rio de Janeiro passe ao posto de capital da colônia brasileira, desbancando a cidade de 
Salvador. Porto e cidade tornam-se ainda mais relevantes quando a Coroa portuguesa, que, fugindo da expansão napoleônica na Europa, se transfere para o Brasil e traz consigo um corpo significativo de burocratas, artistas e intelectuais. A Coroa decide também, na mesma época, abrir os portos brasileiros para navios de todas as bandeiras, abolindo a legislação então existente que restringia o acesso apenas aos navios portugueses.

É verdade que a proibição definitiva do tráfico de escravos em 1850, o qual havia sobrevivido como a própria instituição da escravidão à independência do Brasil em 1822, retira do Porto do Rio de Janeiro uma de suas funções fundamentais. Ainda assim, a expansão concomitante do comércio internacional e o crescimento continuado da exportação do café produzido no Vale do Paraíba mantinham a vitalidade das atividades portuárias.

A proibição do tráfico e a absorção dos escravos remanescentes pela atividade cafeeira são acompanhadas da disseminação de relações de trabalho assalariado no Rio de Janeiro, a qual "era cada vez mais transfigurada pela nova trama de relações sociais que ia se constituindo no espaço urbano" (Benchimol, 1992:44). De fato, a capital do império apresentava nas últimas décadas do século XIX uma estrutura social complexa comportando, conforme o censo de 1870, uma população total urbana de 192.002 habitantes (eram 235.381 habitantes, se incluídas também as paróquias rurais) e uma maioria de homens livres (81\% do total). Cerca de um terço da população total era constituído de estrangeiros (ibid.:79).

Conforme mostra Benchimol (ibid.:96), os transportes urbanos instalados na segunda metade do século XIX desempenham um papel fundamental na estruturação do traçado urbano do Rio de Janeiro. Entregues a empresas privadas "operando numa área de privilégios concedidos pelo Estado", as linhas de bonde partiam do centro para os bairros residenciais da zona norte e da zona sul, permitindo a ligação entre os locais de moradia, sobretudo, da população um pouco mais abastada e a "área central febril, multiforme, superpopulosa e insalubre" (ibid.:96), dominada pelos cortiços nos quais viviam pobres e miseráveis. 
A abolição da escravidão em 1888, a proclamação da República em 1889 e o coetâneo declínio da lavoura cafeeira no Vale do Paraíba se fazem acompanhar de mudanças importantes para o Rio de Janeiro. Ao lado da explosão populacional (entre 1870 e 1890, a população da cidade duplica, saltando para 522.651 habitantes, $24 \%$ dos quais estrangeiros), várias unidades industriais vão se instalar nesta ocasião na capital federal, produzindo bens de consumo como tecidos, alimentos, calçados para um crescente mercado interno que se expandia rapidamente (Benchimol, 1992:172-174). Entre os novos habitantes da cidade encontra-se um contingente importante de pessoas vindas de Salvador, a maior parte delas ex-escravos:

Ao chegar ao Rio, eles se estabeleceram a princípio na Saúde, o antigo Valongo, onde a moradia era barata e o porto oferecia oportunidade de trabalho braçal. Em comum, tinham uma identidade mais definida: negros de origem sudanesa, eles chegavam de Salvador trazendo uma ampla experiência tanto cultural, com sua participação em grupos festeiros, como religiosa, nos candomblés (Figueiredo $2005: 185)^{6}$.

Esse é o contexto mais geral no qual se inserem os diferentes projetos de reforma urbana e portuária desenvolvidos na virada para o século XX. Expressivas são aqui, sobretudo, as obras desencadeadas por Rodrigues Alves, que assume a Presidência da República em 1902. Contrariando sua alcunha, o Soneca, Rodrigues Alves dedica-se com fervor à tarefa de modernizar a capital federal. Manda ampliar as áreas de circulação viária na região central, e promove uma ampla reforma do porto do Rio de Janeiro. As obras são financiadas através de um vultuoso empréstimo da Casa Rothschild e por capital nacional, "captado mediante a emissão de apólices especiais" (Figueiredo, 2005:175). O ciclo de modernização urbana dos primeiros anos do século XX é completado pelas ações do prefeito Pereira Passos que governou a cidade entre 1902 e 1906.

O porto vai perdendo gradativamente sua importância ao longo do século XX, na mesma medida em que as terras de seu entorno. Com a mudança da capital federal, em 1960, para Brasília e o crescente esvaziamento político e econômico do Rio de Janeiro, a situação se agrava ainda mais para a zona portuária, que não é alvo de nenhum dos grandes investimentos em infraestrutura e renovação urbana, dirigidos para outras regiões da cidade durante os governos militares. 
Este quadro só começa a se reconfigurar nos anos 1980 quando a Associação Comercial do Rio de Janeiro propõe demolir várias edificações da região para construir um centro comercial, aproveitando as possibilidades de embarque e desembarque oferecidas pelo porto. Trata-se, claramente, de uma tentativa de acumulação entrelaçada, no sentido descrito acima, na medida em que buscava incorporar um espaço debilmente integrado à dinâmica de acumulação ao projeto de retomada do dinamismo do desenvolvimento capitalista no Rio de Janeiro. O projeto esbarra na resistência da população local que se organiza e logra obter o tombamento como patrimônio histórico de 1.100 edificações da zona portuária, conforme mostra a cuidadosa reconstrução de Vassallo (2015:64) ${ }^{7}$.

Ainda conforme a autora, os planos de reformar, urbanisticamente, a área portuária são retomados pelos prefeitos Cesar Maia (1993-1996 e 2001-2008) e Luís Paulo Conde (1997-2000), que modificam a legislação de uso e ocupação do solo urbano, de sorte a criar as condições legais para a realização das intervenções desejadas na zona portuária. O projeto Porto Maravilha, deslanchado já na gestão de Eduardo Paes em 2009, concretiza e materializa as tentativas anteriores, gerando mudanças substantivas na forma de integração das áreas contíguas ao porto à acumulação do capital.

\section{O PORTO, A CIDADE E SUAS LEIS}

A longa história resumida muito brevemente na seção anterior é, de certo modo, recontada e detalhada, na presente seção a partir de legislações que tiveram papel-chave na reconfiguração dos processos de criação de valor no espaço do porto e áreas contíguas.

Ponto de partida: a Ordem Legal do governador Rui Vaz Pinto de 1618 e a disputa pela tomada dos terrenos da região portuária

Já no início do século XVII é possível constatar o primeiro grande aumento do movimento do porto do Rio, naquele período conectado apenas à vazão do açúcar produzido nos engenhos do recôncavo da Baía de Guanabara. Tal movimento levou o governador Rui Vaz Pinto a editar, em 1618, ordem legal que determinava o emprego de escravos negros $^{8}$ na carga e descarga dos navios (Lamarão, 2006:22-23). Tratava-se claramente de um mecanismo de tomada do espaço para 
criação de valor, na medida em que o carregamento de mercadorias no espaço do porto ficava restrito a proprietários de escravos e, como se verá, a um em particular. Ao mesmo tempo, essa ordem não apenas confirmava a presença de mulheres e homens negros no trabalho urbano, mas os assentava na região portuária que, até então, servira apenas como porta de ingresso dos escravos. Tal ordem representou, ainda, o início dos serviços regulares de estiva e estabeleceu seu regime jurídico, a saber, o privilégio ou o monopólio, na medida em que o direito de execução do serviço foi delegado a um concessionário privado, o irmão do governador (ibid.:p. 22). Note-se que, nesse tipo de acumulação, o direito opera como um agente da reserva de mercado com vistas a beneficiar uma pessoa específica.

Paralelamente à regulação dos serviços e atividades portuárias, toda a área foi objeto de conflitos entre moradores, oficiais da câmara e funcionários régios ao longo do século XVII e na primeira metade do século XVIII, como mostra o estudo de Bicalho (2007). Esses conflitos pela posse e uso do solo que se urbanizava estão refletidos num acórdão redigido pela câmara municipal em meados do século XVII, que autorizou a venda dos terrenos da marinha que lhe pertenciam, com o fim de arrecadar recursos para a construção de um forte.

Os conflitos em torno da posse do solo na região se acirram dramaticamente quando, em 1725, o Provedor da Fazenda Real do Rio de Janeiro pede em carta a D. João V, o rei de Portugal, que as casas e outras edificações da região fossem removidas para dar lugar à expansão das atividades portuárias. Chamados pelo rei a contestar, os oficiais da câmara defenderam as edificações por causa da importância das vendas dos terrenos como fonte de seus próprios recursos e do respeito aos direitos adquiridos dos moradores sobre os terrenos (ibid.:10). A partir das descrições de Bicalho sobre as alegações oferecidas pelos oficiais da câmara, nota-se o recurso de uma noção de justiça baseada em uma espécie de princípio da compensação. Conforme tais oficiais, os moradores, por seus próprios esforços, tiveram o mérito de transformar uma área vazia e alagadiça em um espaço urbano, que veio a ser fundamental para o desenvolvimento das atividades portuárias.

A contenda jurídica acima descrita bem como a Ordem Legal do governador Rui Vaz Pinto revelam a rede complexa de relações entre atores públicos e privados que conformam o processo de acumula- 
ção. Durante todo o século XVII, o favorecimento do irmão do citado governador na execução dos serviços de estivas, o emprego de mão de obra de escravos negros e a aliança entre oficiais da câmara e proprietários dos terrenos portuários indicavam áreas de sinergias entre o público e o privado que viabilizavam a acumulação em diversas dimensões: consolidação de trabalho escravo em atividade-meio, arrecadação de recursos pecuniários, ocupação e transformação do espaço. Houve, nesse sentido, uma parceria público-privada em sentido lato, que viabilizou a tomada capitalista de toda a região.

Além disso, como se pode ainda depreender das justificativas dos oficiais da câmara, tal tomada fez amplo uso da figura retórica das "terras vazias", no mesmo sentido já apontado por Backhouse (2015). O caráter violento dessa retórica no processo de expropriação da terra ficou ainda mais claro, pois, como demonstrado por recentes pesquisas arqueológicas, a região portuária, justamente no século XVII, encontrava-se ocupada por grupos indígenas (Tavares, 2012:124-125). Assim, enquanto recurso linguístico, o emprego da expressão "terra vazia" desempenhou um papel fundamental no exercício da violência estatal colonial presente na acumulação primitiva do capital: cria-se arbitrariamente títulos e transferências de direitos de propriedade (entre os oficiais da câmara e os moradores) que, no entanto, servem à expropriação da população local e ao esbulho de seu espaço.

O início do século XVIII é marcado pela política de aprofundamento da integração do porto do Rio de Janeiro na economia mercantil. Para essa política, as condições anteriores de acumulação (favorecimento pessoal nos serviços de estiva, vendas de propriedade e edificações particulares) eram insuficientes e tornavam-se barreiras ou fatores de bloqueio para a continuidade da acumulação. Essa nova fase de expansão capitalista não implicou, todavia, renúncia à estratégia de parcerias público-privadas. Ao contrário, a solução da contenda entre os moradores, oficiais da câmara e funcionários régios, encontrada por $\mathrm{D}$. João $\mathrm{V}$, indicava a necessidade de reconciliação entre atores públicos e privados. Assim, no final de 1726, o rei decidiu favoravelmente aos argumentos da câmara relativos à manutenção das edificações existentes, contrariando os interesses do Provedor da Fazenda Real. No dia 10 de dezembro do mesmo ano, no entanto, atendeu a parte das solicitações do Provedor e decretou uma Carta Régia, cujo conteúdo prescrevia que "daqui em diante [...] ninguém se possa alargar um só palmo para o mar, nem edificar casas nas Praias até a 
ponta do Valongo" (Tavares, 2012:10). A continuidade da acumulação exigia, assim, não o rompimento, mas outro padrão de relações público-privadas. Isso estava vinculado à inauguração de uma nova etapa de expansão do capitalismo mercantil, baseado em um novo quadro de intervenções regulatórias nos processos de mercantilização do espaço portuário.

Expansão do movimento portuário e a transferência da capital para o Rio de Janeiro: o Ofício de 8 de junho de 1763

Ao longo da primeira metade do século XVIII, a descoberta das reservas de ouro e o elo entre Minas Gerais e o capital mercantil aumentou a importância do porto e da cidade do Rio de Janeiro. Em razão da maior proximidade (em relação ao porto de Salvador) e da existência prévia de conexões (como os Caminhos Velho e Novo) com a região mineradora, passou a existir um fluxo regular entre o Rio de Janeiro e estas regiões (Honorato, 2008:31). Isso levou ao aumento significativo, no porto, da frequência de navios metropolitanos que transportavam o ouro para a Europa e traziam alimentos, tecidos e escravos para o Brasil. Enquanto o porto do Rio se tornava o principal entroncamento comercial com a metrópole, a cidade se expandia econômica, física e demograficamente, tornando-se, a partir de 1763, a capital da colônia (Lamarão, 2006:25-26; Hilf, 2012:59).

A decisão de transformação do Rio de Janeiro em capital foi determinada por Ofício do Marquês de Pombal, de 8 de junho de 1763, que, além de informar o decreto do rei José I, de 11 de maio do mesmo ano, que nomeava o Conde da Cunha como novo Vice-Rei do Brasil, exigia também que sua residência seria na cidade do Rio de Janeiro (Da Silva, 2012:55). Esse entrelaçamento entre porto e cidade estimulou, durante os séculos XVIII e XIX, importantes mudanças na região portuária, como a abertura de novas vias, ocupações e edificações de novos cais, arsenais etc., o que por sua vez favoreceu o desenvolvimento urbano do Rio de Janeiro (Cardoso et al., 1987:27).

Em resumo, durante todo esse período, tem-se a realização da acumulação entrelaçada nas três formas distintas de inserção do porto na dinâmica da acumulação, descrita acima, a saber, na sua função-fim (que facilita a integração de Minas Gerais na economia mercantil), no próprio espaço do porto (otimização dos serviços portuários) 
e na relação entre o porto e a cidade (ocupação do entorno portuário). No âmbito da acumulação mercantil, há uma articulação entre essas três dimensões, na medida em que a integração brasileira à dinâmica de acumulação global faz crescer os ganhos na exploração dos serviços portuários e estimula ocupações sucessivas no perímetro do porto - tanto a tomada de áreas externas ainda não urbanizadas quanto a retomada de um "exterior" que se descapitalizou por não atender às alterações do fluxo do movimento portuário. Na região do porto, isto representou uma mudança das relações de propriedade em diversas freguesias, onde chácaras eram convertidas em moradias, passando a força de trabalho escrava antes empregada em atividade agrícola para o trabalho urbano (Moura, 2007:81; Honorato, 2008:36 e 59; Lamarão, 2006:38).

Conforme os modelos geográficos clássicos, esse intercruzamento descrito é explicado pela noção de "trajetória simbiótica cidadeporto", segundo a qual haveria uma "fecundação recíproca" entre os dois elementos, de modo que o porto seria fator de atração e influência no sistema urbano da cidade (Ducruet, 2005:2-3; Bird, 1957:178). Essa literatura parte da tese de que o comércio marítimo deu origem a uma série de assentamentos (Norcliffe, Basset e Hoare, 1996:124). De um lado, porque depende do florescimento de empresas e empregos, necessários tanto para a vazão comercial dos bens (não apenas a manipulação física das cargas, mas também a emergência de negócios de financiamento e seguros), quanto para a construção e manutenção técnica dos navios (Witherick, 1981; Hilling, 1988). De outro, porque atrai produtores e consumidores em torno da cidade portuária, o que era ainda mais forte no caso das colônias, onde o porto significava o armazenamento de bens raros da metrópole e processamento dos produtos primários advindos da atividade agrícola ou mineradora (Innis, 1956; Couper, 1972:48).

As Ordens Legais do Segundo Marquês do Lavradio (1769-1779): comércio e disciplinamento de escravos no porto do Rio de Janeiro

Desde que o Rio de Janeiro se tornou o maior entroncamento comercial do Brasil, a relação porto-cidade é apresentada como convergente e profícua, capaz de combinar aumento do movimento de navios, intensificação dos fluxos comerciais, desenvolvimento tecnológico e expansão da urbanização (Santos, 1995:257-268). Na zona portuária, essa trajetória simbiótica significou valorização do capital pela toma- 
da do espaço por meio da construção de edificações (de habitações e escritórios a armazéns), abertura de ruas, adensamento populacional e aceleração do comércio local (Honorato, 2008:130). Dentre essas transformações geradas pela confluência porto-cidade do Rio de Janeiro, a mais importante foi, no entanto, a ordem do Segundo Marquês do Lavradio (Vice-Rei do Brasil entre 1769-1779), de 12 de abril de 1774, que referendou o Edital da Câmara de 1758, determinando a mudança do mercado de escravos da rua Direita para o Valongo (Honorato, 2008:34 e 73-74; Lamarão, 2006:27). Com isso, todos os negociantes de escravos - que, em sua totalidade, dos grandes aos "atravessadores", eram empreendedores privados - se transferiram para o perímetro do porto (Honorato, 2008:64). ${ }^{9}$

Diferentemente do ato anteriormente descrito do governador Rui Vaz Pinto em 1618, que privilegiou o favorecimento pessoal, na nova acumulação, a ordem legal do Marquês do Lavradio estimulou os agentes econômicos autônomos. Para viabilizar a circulação do fluxo de seus negócios e capital foram feitas diversas obras urbanas. Entre elas, como descreve Mello (2003:31), pode-se mencionar o aterro de mangues, a ampliação de áreas secas, a abertura de ruas para a facilitação do tráfego no entorno do mercado de escravos e a criação da rua do Livramento, que permitiu a ocupação da nova área. A criação e a tomada do espaço dinamizaram a atividade econômica da região (Lamarão, 2006:27; Mello, 2003:30-31). Em busca do mercado de escravos, a população passou a frequentar a zona portuária, tornando-a um dos pontos mais movimentados do Rio de Janeiro (Haag, 2011:26; Pereira, 2007:76).

O aumento da circulação do capital era evidenciado pelo elevado número de estabelecimentos que negociavam escravos, então conhecidos como "casas de carne", que a região passou a abrigar - cerca de 50 no total (Pereira, 2007:76; Hilf, 2012:61). Enquanto maior mercado de escravos do mundo, estima-se que por volta de 1 milhão de mulheres e homens sequestrados na África passaram pelo Valongo (Honorato, 2008:18 e 83; Hilf, 2012:61; Tavares, 2012:54) ${ }^{10}$. Conforme mostra a literatura, toda essa agitação comercial estimulou a expansão urbana para o norte da cidade, onde a acumulação do capital gerada pela intensa atividade econômica podia se realizar para fora dos limites em que ela se formou (Pereira, 2007:76). 
Ao lado do dinamismo econômico da região portuária, há o desenvolvimento simultâneo de técnicas de repressão e disciplinamento da população negra que chegava para ser a força de trabalho (escrava) (Tavares, 2012:42). A justificativa para essas técnicas foi primordialmente a vigilância sanitária e a saúde pública (Haag, 2011:25; Hilf, 2012:60; Honorato, 2008:68). O debate que fundamentou o Edital da Câmara de 1758, que prescreveu em primeiro lugar a mudança do mercado de escravos para o Valongo, foi corroborado por diagnósticos médicos. Tais diagnósticos sustentavam que as doenças presentes na cidade eram trazidas por "pretos novos" - como eram chamadas a pessoas recém-chegadas da África - e difundidas entre os moradores por causa do transporte e exposição para venda no centro da cidade (Honorato, 2008:68).

No mesmo sentido, a Ordem do Marquês do Lavradio, que ratificou o edital, se propunha a combater "o terrível costume de que todos os negros que chegavam da costa d'África a este porto, logo que desembarcavam, entravam para a cidade, vinham para as ruas públicas e principais d'ella, não só cheios de infinitas moléstias [...]"11. Para regulamentar essa Ordem, logo que o mercado passou para o Valongo, a Câmara Municipal tornou-se responsável pela inspeção de saúde dos recém-desembarcados e, quando diagnosticados como doentes, determinava que eles fossem colocados em quarentena nos trapiches e lazaretos da cidade (Honorato, 2008:115). Em razão da ganância dos traficantes, da escassez de médicos e do imaginário popular sobre a capacidade curativa dos sangradores, o tratamento consistia em sangrias feitas por barbeiros negros, que geralmente resultava em mortes (Haag, 2011:25; Honorato, 2008:116).

Após a mudança do mercado de escravos, sobreveio outra Ordem do Marquês do Lavradio que determinava o estabelecimento do Cemitério dos Pretos Novos no Valongo. Junto com essa ordem foi definida a regra de que "Os escravos que não forem vendidos não sairão do Valongo nem depois de mortos" (Pereira, 2007:74; Haag, 2011:26). O cemitério funcionou de 1772 a 1830 e serviu para o sepultamento de mulheres, homens e crianças africanos que faleciam após a entrada na Baía da Guanabara e antes de serem vendidos no mercado (Carvalho, 2007:8). Recentes pesquisas de escavação do Cais do Valongo estimam que o cemitério recebeu mais de 20 mil corpos (Haag, 2011:26). Esse alto índice de mortalidade revela as condições às quais, após o rapto na África, mulheres, homens e crianças eram submetidos nos navios, no lazareto e no mercado. Esses dados se contrapõem à tese 
muito difundida na historiografia, segundo a qual, em função do lucro, a proteção da "mercadoria" relativizava o sofrimento imposto aos escravos.

O processo de acumulação relaciona-se menos com a obtenção de lucro apropriável pela venda da mercadoria (Marx, 1983:45) e muito mais com a formação de relações sociais desiguais geradas por expropriações violentas, as quais depende do disciplinamento da força de trabalho (Dörre, 2012:65). O Complexo do Valongo era um lugar fundamental na longa linha de subordinação da mão de obra escrava, que se iniciava na captura e imigração forçada. Enquanto, no momento que se encontravam no porto, o modelo punitivo de direito e política sanitários preponderava, no mercado, recorria-se primariamente ao modelo penal tradicional de controle social pelo emprego de técnicas de maus-tratos, torturas físicas e morais, privação de alimentos e cuidados etc.

A família real no Rio de Janeiro e os atos régios sobre o Valongo: intensificação das parcerias público-privadas como instrumento das políticas sanitárias e penais do processo de acumulação

Ainda que a mudança já houvesse sido cogitada anteriormente, as guerras expansionistas de Napoleão Bonaparte, na Europa, foram a razão imediata que levaram a coroa portuguesa e a família real a se transferirem para o Rio de Janeiro, chegando ao Brasil em 1808. Abrem-se os portos brasileiros a navios de diferentes bandeiras e, com a presença da Coroa com suas dezenas de milhares de funcionários e as reformas urbanas introduzidas, modificam-se as formas de ocupação e uso do espaço urbano do Rio de Janeiro e, por conseguinte, reconfigura-se a acumulação no porto da cidade.

Disposições jurídicas sobre a saúde dos escravos novos: a política sanitária da coroa na região portuária e o Lazareto (privado) do Valongo

Se nos anos iniciais da Ordem do Marquês do Lavradio predominou o modelo de higienização executada diretamente pela municipalidade (sem delegação) que buscava confinar os doentes, excluindo-os de qualquer contato social, com o passar do tempo esse modelo se tornou uma estrutura muito mais complexa. O Regimento de 22 de janeiro de 1810 determinava que as embarcações com carregamento de escravos 
deveriam realizar duas ancoragens: na Enseada de Boa Viagem ou no Paço, eram inspecionadas pelos oficiais da saúde que determinavam o tempo de quarentena na Ilha de Bom Jesus, para onde eles deveriam seguir viagem. Sãos e doentes deveriam ser confinados na ilha e, durante a quarentena, selecionados para destinos diferentes. Aqueles que faleciam - e a mortalidade era alta - saiam da Ilha diretamente para o Cemitério dos Pretos Velhos (Tavares, 2012:83).

A obrigatoriedade das duas ancoragens foi objeto de Representação dos negociantes de escravos ao príncipe regente, alegando que ela implicava prejuízos financeiros em função da demora desnecessária, dos riscos de contaminação dos sãos e (contraditoriamente) da pouca gravidade das doenças, as quais, segundo os negociantes, podiam ser diretamente tratadas nos navios ou nas casas. Ainda que cada uma dessas alegações tenha sido contestada pelo Provedor-Mor da Saúde com base em questões sanitárias, chegou-se a um consenso que levou à criação do Lazareto do Valongo no Monte de Nossa Senhora da Saúde, conforme o Aviso Régio, de 23 de setembro de $1810^{12}$. Se considerarmos que, como mostra Pereira (2007:106), muitos dos escravos sepultados no Cemitério dos Pretos Velhos vinham do novo Lazareto, conclui-se que não houve mudanças substantivas em relação ao contexto anterior já descrito.

A novidade consistia na adequação do modelo punitivo sanitário às exigências do padrão de acumulação consolidado na região portuária que, com a determinação da transferência do mercado de escravos, passava a estimular os agentes econômicos autônomos. Isso fica evidente no desenlace amigável da contenda entre o Provedor-Mor da Saúde e os negociantes de escravos, quando o Aviso Régio acima citado determinou que o Lazareto do Valongo fosse construído por três dos principais negociantes/traficantes de escravos do Brasil matriculados na Real Junta do Comércio ${ }^{13}$ e que o terreno lhes fosse adjudicado pelo preço arbitrado por vistoria. O mesmo Aviso os declarava proprietários do Lazareto. Pelos serviços prestados, os demais negociantes deveriam pagar 400 réis por escravo recolhido, valor esse que conforme o Provedor-Mor da Saúde serviria, inclusive, como compensação pelas despesas com a compra do terreno e a construção do Lazareto (Honorato, 2008:105; Pereira, 2007:106). 
A alta porosidade da fronteira entre o Estado e os atores privados confirma que parcerias público-privadas em sentido amplo foram fundamentais para a acumulação entrelaçada analisada. Note-se que, no Aviso Régio apresentado, o Estado delega o uso exclusivo da prestação de serviço de saúde aos três negociantes/traficantes de escravos e ordena que a contraprestação seja garantida por agentes privados, quais sejam, os demais negociantes obrigados a enviar escravos novos doentes ao Lazareto do Valongo. Como mostra Pereira (2007:108), esse arcabouço institucional estava adequado à lógica escravista no Rio de Janeiro oitocentista, que buscava promover a diversificação das empreitadas econômicas. Tal diversificação fazia parte do processo de expansão do capitalismo mercantil que, na região portuária, materializou-se na ocupação dos terrenos do Monte da Nossa Senhora da Saúde pelos atores do mercado de escravos.

A delegação dos serviços de saúde permitiu, ainda, a desoneração por parte do Estado dos altos custos econômicos (quanto ao volume de gastos no tratamento da grande quantidade de escravos doentes desembarcados) e políticos (reclamações constantes dos comerciantes contra o Provedor-Mor da Saúde), gerados pela implementação da política sanitária. Assumida igualmente pelos atores privados, essa política reforçava seu caráter de disciplinamento da força de trabalho.

Acumulação e disciplinamento entre o regime jurídico público e o privado: da legislação penal sangrenta à ineficácia do Alvará de 24 de novembro de 1813

Essa estrutura repressiva se ampliava no mercado de escravos, no qual, como afirmado, se recorria amplamente aos meios do modelo penal tradicional de controle social. Para se ter uma ideia de como esse modelo funcionava no Valongo, basta recorrer aos diversos relatos de viajantes, documentados amplamente nas pesquisas de Pereira $(2007 ;$ 2013), Tavares (2012) e Honorato $(2008 ; 2006)$.

Conforme os relatos, mulheres, homens e crianças eram expostos à venda como qualquer outro artigo de consumo, ao lado de gêneros alimentícios e outras mercadorias (Pereira, 2013:225 e 240). Muitos dos viajantes enfatizavam que as cabeças dos escravos eram raspadas e todos se encontravam praticamente nus, apenas com um pedaço de pano que os cobriam na altura da cintura (Honorato, 2008:77-78; Tavares, 2012:93; Pereira, 2007:240). Eram confinados e frequentemente espancados e comercializados através dos mesmos métodos usados 
para o tratamento e venda de gado (Honorato, 2008:77-87 e 85). No momento da venda, os cativos eram obrigados "a mostrar os dentes, estender violentamente braços e pernas, correr e gritar para mostrar saúde" (ibid.:85). Ao lado do mercado, para facilitar as práticas mercantis, o Estado criou depósitos no Trapiche do Valongo, nos quais se podiam recolher os escravos após o período de sua exposição à venda (id.:34).

Não havia também qualquer restrição a que membros de uma mesma família fossem vendidos independentemente, de sorte que crianças eram separadas de seus pais e casais estáveis eram muitas vezes condenados a nunca mais se verem, como registra, estupefato, o jovem Charles Darwin (1959) em sua passagem pelo Rio de Janeiro em 1832.

O modelo penal tradicional de controle social se estendia dos depósitos públicos de escravos às casas do mercado. Nelas, os comerciantes eram responsáveis por toda sua rotina (Tavares, 2012:86). Isso significa que, juntamente com as políticas estatais repressivas, havia o exercício de um direito penal privado em que os próprios comerciantes impunham parâmetros de comportamentos e castigos. Nesse sentido, também nos espaços de adoção do modelo penal tradicional era possível encontrar um alto grau de sinergias público-privadas. Entre as "miseráveis habitações" do mercado e os armazéns estatais do trapiche, os escravos eram submetidos a um estado permanente de disciplina e punição.

Embora à primeira vista tais métodos sugiram o contrário, discursos lamentando perdas econômicas derivadas dos maus-tratos também existiram. Podem ser encontrados nas reclamações dos comerciantes sobre os enormes danos em seus negócios provocados pelos métodos empregados na Ilha de Bom Jesus (Honorato, 2008:102) ou nas justificativas do Provedor-Mor da Saúde para defender a quarentena enquanto garantia de bons negócios para proprietários dos navios, comerciantes e compradores (ibid.:104). O mais eloquente desses procedimentos foi o Alvará, de 24 de novembro de 1813, que regulou a operação de carga, transporte e descarga de mulheres e homens negros. Tal alvará apresentava o escravo como uma carga viva mercantil que precisava permanecer viva e saudável para gerar lucro. Assim, ele prescrevia uma série de "melhorias", como, por exemplo, substituição de marcas de ferro por argolas, embarcamento de um 
cirurgião para que o número de mortos não ultrapassasse $2 \%$ ou $3 \%$ da carga, necessidade de alimentação, água potável, movimentação diária, arejamento etc.

Apesar do Alvará, diversas evidências apontam para o fato de que os maus-tratos, os confinamentos e o número elevado de mortes nunca cessaram. Em 1815, o Intendente Geral da Polícia enviou ofício ao Juiz do Crime da Sé, requerendo a limpeza de um dos pântanos do Valongo que se tornou depósito de corpos, utilizado pelos comerciantes para evitar as despesas com os enterros no Cemitério dos Pretos Novos. Este, por sua vez, só poderia justificar sua existência em razão de uma taxa de mortalidade tão alta (Pereira, 2007:113). Além disso, pesquisas recentes em ossos retirados do respectivo cemitério mostram que eles apresentavam "sinais de maus-tratos, como fraturas, infecções, anemias e degenerações" (Pereira, 2007:134). Particularmente, a constatação de anemia era indício da manutenção permanente de péssima nutrição dos escravos, o que, por sua vez, favorecia a contração de doenças (Haag, 2011:29).

O problema da ineficácia do Alvará pode ser compreendido à luz do processo de circulação do capital na acumulação mercantil. Ao confrontar a taxa anual de entradas de escravos africanos no porto do Rio com a de sepultamento no Cemitério dos Pretos Novos, Pereira (2007:113) constatou que mais mortes significavam a necessidade de importar cada vez mais escravos. Do mesmo modo, Honorato $(2008: 77 ; 2006: 2)$ identificou que a presença de relatos negativos em relação à região aumentava proporcionalmente aos períodos de grandes importações de escravos, o que, segundo o autor, confirmava que, nesses períodos, eles eram mais mal-tratados, pois os excessos eram mais visíveis. A convergência dessas variáveis indica que a acumulação mercantil mantém, ao mesmo tempo, o lucro médio obtido pelas atividades comerciais e o disciplinamento da força de trabalho. Ambos tornavam o escravo vendável e atrativo no mercado e viabilizavam as condições iniciais para a apropriação de trabalho escravo pelas empresas exportadoras, cujo produto retorna à atividade comercial. Com isso, morte, repressão e controle se tornaram fatores fundamentais da expansão da acumulação mercantil.

Esses mecanismos, típicos do modelo penal tradicional de controle social, estimularam, inclusive, o surgimento de empreendimentos econômicos voltados à produção dos meios necessários à sua exe- 
cução. Nesse sentido, a instalação de uma manufatura de objetos de ferro destinados à prisão e torturas de escravos na zona portuária tem uma relevância simbólica fundamental no desenvolvimento da respectiva acumulação (Hilf, 2012:60). Ainda mais se notarmos que tal instalação é considerada um fator relevante da ocupação, urbanização e movimentação econômica da região (Mello, 2003:30-31). Empregados pelo direito penal privado, os instrumentos de disciplinamento não apenas minavam o alcance do Alvará de 24 de novembro de 1813, mas também podem explicar porque ele foi revogado pelo Alvará de 26 de janeiro de 1818, que substituiu a exigência de cirurgiões pela de negros sangradores, bem como reintroduziu a marca a ferro quente (Tavares, 2012:68).

\section{O Cemitério dos Pretos Novos e a desvalorização da região portuária}

Dos métodos de disciplinamento empregados, a construção do Cemitério dos Pretos Novos é, sem dúvida, o mais expressivo e se coloca diretamente relacionado com as estratégias de acumulação da zona portuária e da cidade. Em primeiro lugar, embora ainda não se saiba seu tamanho exato, ele foi colocado em uma posição estratégica no meio do caminho entre o Lazareto do Valongo e o mercado (Tavares, 2012:83). Nesse local, como mostrado pela ampla pesquisa de Pereira (2007:74), os corpos eram enterrados nus, sem nenhum tipo de sacramento religioso, em valas comuns e covas rasas "à flor da terra", de modo que os defuntos ficavam praticamente expostos à luz do sol. Uma vez que sua localização na região permitia sua visibilidade, principalmente do mercado, a ausência de qualquer ritual fúnebre ou de luto era mais um componente que minava a dignidade de africanas e africanos recém-chegados (Pereira, 2007:74; Carvalho, 2007:11). Além disso, conforme os relatos da época, a pouca quantidade de terra jogada sobre os corpos, cujo número era bastante elevado, aumentava a frequência do descobrimento de restos de cadáveres, o que evidentemente intensificava o sofrimento e os temores dos vivos (Honorato, 2006:4).

Esse estado de coisas era administrado pela Igreja, que cobrava dos comerciantes taxas para as inumações. Note-se, portanto, que o cemitério também cumpria uma função para a acumulação. Ao lado dos comerciantes e do Estado, a Igreja era um terceiro ator (privado) que compunha o complexo mercantil que se formava no Valongo. 
Tal retrato produz um efeito fundamental no interior do processo de valorização da própria região portuária e na sua relação com a expansão urbana e econômica da cidade do Rio de Janeiro. Como vimos acima, o período em questão é analisado na literatura pela ideia de "trajetória simbiótica cidade-porto". E, de fato, é possível constatar pelos dados anteriormente levantados que a intensificação do movimento do porto do Rio e a ocupação da área em que ele se localizava impulsionaram o desenvolvimento da cidade. Contra esse "senso comum", a geografia contemporânea sustenta que, na fase da "trajetória simbiótica", já existem pontos de dissociação ou disjunções entre o porto e a cidade (Ducruet, 2005:4). Ao se basear em negócios sujos e perigosos, os setores produtivos portuários dariam lugar apenas a habitações para estivadores e a espaços de diversão de marinheiros/ navegadores, tornando-o a parte menos valorizada do solo e do tecido urbano. Em função disso, as classes comerciantes e outros setores das elites locais tendiam a buscar suas moradias e escritórios em pontos afastados da região portuária, o que geraria não apenas uma separação física com a cidade, mas a constituição das áreas do porto como um mundo social, estético e político à parte (Norcliffe, 1996:125).

Esse fenômeno pode ser observado já na justificativa da decisão do Marquês do Lavradio a respeito da transferência do mercado de escravos para o Valongo (Pereira, 2007:73-74; 2013:223-224). Sua intenção era claramente a de "afastar o incômodo local de venda" para fora do centro da cidade. A partir de um debate que já havia envolvido a Câmara Municipal e os médicos da cidade, o Marquês alegava que a presença de escravos novos em meio às moradias contribuía para a sujeira, a insalubridade e, principalmente, para a difusão de epidemias e doenças que tais escravos traziam da África. Prometia, ainda, que o Valongo seria um local mais organizado e que primaria pela limpeza, de modo que impediria a propagação de chagas pela cidade e diminuiria a mortandade de escravos.

Nesse sentido, a transferência do mercado de escravos se orientou claramente pelo processo de afastamento e invisibilidade desse tipo de comércio. Tratou-se, ainda, de política higienista, de limpeza das regiões ocupadas pela população mais nobre da cidade do Rio de Janeiro. Na linha de Tavares (2012:54), a conclusão mais óbvia é que a construção do complexo do Valongo serviu para "isolar o mercado 
da boa sociedade colonial" e "afastá-lo da visão dos fidalgos". Tal construção importou uma disjunção entre as regiões habitadas pelas classes subalternas e aquelas ocupadas pelas elites.

A partir da lógica da acumulação entrelaçada, é possível reinterpretar esses pontos de disjunção como tendências ao desacoplamento da dinâmica de mercantilização ocorridas no interior do processo de ocupação capitalista do espaço. Tendências essas que são necessárias para a construção de um novo "fora" exigido para manter a acumulação, isto é, um novo espaço não capitalista, que, quando se generaliza, dá origem a uma nova dinâmica de reincorporação ao processo de acumulação.

A chegada da família real tornou essa cisão ainda mais visível. A partir de 1808, o número de importação de escravos novos no porto do Rio aumentou de maneira significativa, juntamente com o número de mortos enterrados no cemitério (Carvalho, 2007:12) e com o aumento de relatos negativos de viajantes a respeito dos maus-tratos e insalubridades do mercado (Honorato, 2008:74). Ao mesmo tempo, a família real desencadeou a implementação de políticas urbanas, como o Edital de 11 de junho de 1808, que, por meio de diversos melhoramentos de infraestrutura, incentivou a expansão da cidade (Honorato, 2008:59). Esse tratamento diferenciado para a região portuária consolidou-a como espaço de "brancos pobres, escravos de ganho ou negros libertos que ganhavam a vida com trabalhos esporádicos no porto" (Pereira, 2007:34). O cemitério e o mercado só seriam fechados com o início da vigência do tratado de extinção do tráfico de escravos imposto pela Inglaterra (Pereira, 2007:129). Nesse momento, a região vai perdendo importância como espaço da acumulação até o início do século XX, quando será objeto das reformas urbanísticas do prefeito Pereira Passos.

\section{$\mathrm{O}$ advento da República e a reforma urbana de Pereira Passos}

As obras federais no porto do Rio de Janeiro desenvolvidas durante o governo de Rodrigues Alves respondiam à tendência internacional de substituir o trabalho braçal humano por guindastes e máquinas a vapor, como havia se dado pioneiramente no porto de Londres e mais tarde no porto de Buenos Aires. O cais do porto vai sendo expandido por etapas e a obra final, mesmo inconclusa, é inaugurada em 1910 já pelo presidente Nilo Peçanha (Pinheiro e Rabha, 2004:65). Durante as obras, confiadas à construtora inglesa C. H. Walker \& Co. 
Ltd, muitas casas na região do antigo Valongo são sacrificadas, levando que seus moradores, muitos deles ex-escravos migrados da Bahia, se deslocassem para a Cidade Nova (Figueiredo, 2005:185).

As reformas no porto, de alguma forma, revitalizam sua utilidade no âmbito da acumulação global do capital, sobretudo, em suas funções-fim (como porta de entrada e saída de mercadorias para o mercado mundial) e atividade-meio (pelos serviços de embarque e desembarque prestados pelo porto). Relevante é igualmente a integração do Rio de Janeiro, desde então, ao mercado turístico global, na medida em que as novas instalações do porto tornam ponto de parada obrigatória dos grandes cruzeiros que visitavam a América Latina (ibid.:188). Já as áreas acidentadas adjacentes ao porto, como os Morros da Saúde e da Gamboa vêem consolidar seu descolamento da acumulação global. Tornam-se mais e mais desvalorizadas do ponto de vista do mercado imobiliário, servindo de refúgio à população pobre e moradias precárias.

A reforma urbana do Rio de Janeiro, desencadeada pelo prefeito designado por Rodrigues Alves, o engenheiro Pereira Passos, era de certa forma complementar e funcional às obras de modernização do porto, na medida em que a reforma tinha como núcleo a abertura de grandes vias ligando a zona portuária às demais regiões da cidade, facilitando a chegada e saída de produtos do porto para o interior da cidade e do país. As novas vias seguiam também a lógica da cidade orgânica, integrada, no âmbito da qual não só o porto e o comércio nas áreas centrais estavam interligados, mas também as áreas de expansão ao sul (Botafogo, Copacabana etc.) e nos subúrbios (Méier, Engenho Novo etc.) encontravam acesso rápido ao núcleo central, propulsor de "civilização", com seus teatros e faculdades.

Inspirado pela remodelação de Paris conduzida pelo prefeito GeorgesEugène Haussmann entre 1853 e 1870, Pereira Passos busca, ainda, completar a obra do governo federal do ponto de vista da ideologia modernizante, isto é, no sentido de sepultar as marcas coloniais e, a seu juízo, passadistas que ainda marcavam o centro do Rio de Janeiro. Além do programa propriamente urbanístico, Pereira Passos desencadeia uma política higienista e disciplinadora, penalizando comportamentos considerados incompatíveis com a cidade moderna, proibindo práticas religiosas ligadas ao candomblé e punindo manifestações ligadas à música e dança afrodescendentes. 
Isso se deu no mesmo momento em que, precisamente, em torno da região portuária, no âmbito da área chamada "Pequena África" começaram a se desenvolver as manifestações que iriam conformar mais tarde o samba. Desse modo, Pereira Passos, em seu afã de modernizar a antiga capital da colônia, era o portador e operador mais ousado do programa de imitar a Europa e eliminar e reprimir qualquer expressão da cultura popular local que se distanciasse de seu ideal civilizatório:

Na tentativa de impor "civilidade" ao habitante da urbe, Pereira Passos vai emitindo, ao longo de sua gestão, uma série de proibições relativas a práticas urbanas comuns na cidade: proíbe que se cuspa na rua e nos bondes, proíbe a vadiagem de caninos, proíbe que se façam fogueiras nas ruas da cidade, que se soltem balões, proíbe a venda ambulante de loterias, de exposição de carnes à venda nas ruas, também proíbe o trânsito de vacas leiteiras na cidade e andar descalço e sem camisa. Em uma ação conjunta com tais restrições, Pereira Passos busca substituir antigas práticas urbanas por novos hábitos tidos como "civilizados". Desta forma, o prefeito proíbe o entrudo, substituindo-o pela batalha de flores e derruba os quiosques do centro da cidade, estimulando com a sua reforma a abertura de lojas para o chá da tarde (Azevedo, 2003:62-63).

Do ponto de vista que nos interessa aqui, qual seja dos nexos com a acumulação capitalista, a reforma urbana promovida por Pereira Passos reforça, em linhas gerais, os efeitos desencadeados pela "modernização tecnológica" promovida por Rodrigues Alves. O acesso mais fácil entre a cidade e o porto maximiza suas funções como elo entre o Brasil e a economia mundial e propicia a maximização dos ganhos com os serviços portuários, entregues, depois da vultuosa remodelação pública do porto pelo governo federal, ao concessionário privado Daniel Henninger \& Damart \& Comp. "que logo cedeu por transferência seus direitos à Compagnie du Port de Rio de Janeiro" (Pinheiro e Rabha, 2004:71).

Do ponto de vista das terras contíguas ao porto há que se diferenciar entre as áreas planas, em parte expandidas por aterros e demolições, e as áreas nos morros adjacentes (Saúde, Providência, Gamboa e Santo Cristo). As áreas planas, de propriedade do governo federal, são ocupadas por armazéns e repartições públicas, permanecendo ainda "vazios" que só seriam ocupados em reformas futuras (ibid.:68). Os morros, por sua vez, são ocupados cada vez mais pela população pobre, tanto aquela desalojada dos cortiços da área central, que Pereira Passos mandou 
demolir, quanto dos novos migrantes que chegavam à cidade. Nos dois casos, tratam-se de terras urbanas que não fazem parte, propriamente, do mercado imobiliário, e ainda que tenham algum valor de troca, encontram-se desintegradas do circuito de acumulação capitalista.

\section{Intervenções viárias e o desacoplamento entre porto e acumulação}

Com a falência do modelo agroexportador e o contexto internacional adverso nas primeiras décadas do século $X X$, advêm dificuldades de importação de produtos manufaturados, ao mesmo tempo que, do ponto de vista da política interna, as oligarquias rurais que dominavam o cenário nacional perdem sua hegemonia. Inicia-se um período de forte intervenção do Estado na economia com o objetivo de indução do processo que ficou conhecido como ISI, industrialização pela substituição de importação. Isto leva, sobretudo a partir dos anos 1940, a uma ampla expansão das atividades industriais através da diversificação da produção de bens de consumo, que passa a incluir, crescentemente, bens de consumo duráveis, e do impulso à produção de bens de produção, bem como da criação de uma variada gama de mecanismos e instituições próprias ao Estado desenvolvimentista, a saber, um conjunto de agências especializadas no financiamento da indústria, na gestão das políticas industriais e setoriais, no controle da política monetária etc. (Cano, 2015:446; Fonseca e Salomão, 2016).

Estas mudanças rumo ao desenvolvimento das atividades industriais refletem-se nas formas de ocupação do espaço urbano. Durante o período daqueles primeiros impulsos industrializantes que estiveram restritos a setores mais tradicionais, o grosso das atividades industriais estava situado nas áreas mais centrais da cidade do Rio de Janeiro. Já nos anos 1950, o crescimento da concentração das empresas e o aumento de tamanho das plantas industriais exigiram o deslocamento das atividades para a região suburbana e para outros municípios do Rio de Janeiro. Como mostram Oliveira e Rodrigues (2009:132), o processo de esvaziamento da importância da cidade do Rio de Janeiro como centro industrial prosseguiu em passos acelerados nas próximas décadas.

As consequências dessa reconfiguração econômica para o porto do Rio de Janeiro e seu entorno são evidentes. Em sua atividade-fim, ou seja, permitir a entrada e saída de mercadorias, o porto mantém sua relevância até a Segunda Guerra Mundial, quando cede sua importância 
para outros portos brasileiros mais bem adaptados para a circulação dos volumes de carga crescentes. Desde então, a região portuária se torna, em todos os três âmbitos destacados acima, qual seja, como elo da economia brasileira à economia mundial, como espaço de produção de valor pela prestação de serviços portuários e como espaço físico da região portuária, pouco relevante para a acumulação de capital. Consequentemente, os imóveis da região, ainda que centrais, apresentavam baixo valor de mercado, tornando-se, em comparação com a zona cada vez mais valorizada - de expansão ao longo da costa em direção ao sul e mesmo em comparação com as novas oportunidades de negócios surgidas com o adensamento dos subúrbios da zona norte, um território pouco interessante para a inversão e acumulação capitalista. Pesa, neste processo, a expansão viária na área central e, sobretudo, a inauguração, em 1944, de avenida idealizada pelo então ditador brasileiro Getúlio Vargas e batizada com seu nome. Com a construção da avenida Presidente Vargas, a região portuária foi "separada da parte vital do Centro por uma via expressa de 16 pistas de difícil travessia" (Cardoso, 2015:188) ${ }^{14}$.

Ao lado da avenida Presidente Vargas, o Elevado da Perimetral, construído em 1950 e que permitia veículos trafegarem pela região por uma ponte elevada, e outros projetos viários geograficamente instalados na região portuária e suas adjacências são, todos eles, medidas que desvalorizam ainda mais o solo urbano daquela área. Isto é, todas estas obras viárias visavam ligar polos estratégicos do ponto de vista econômico e político, a saber, a área centro-sul e o novo aeroporto internacional criado em 1952, a saída para estados vizinhos, o vínculo entre a zona norte, onde vive o grosso da população trabalhadora, e os locais de trabalho e prestação de serviço na zona sul etc. Nessas ligações, a zona portuária é mera área de passagem, paisagem esvaziada de sentido e conteúdo para quem trafega e quer chegar o mais rápido possível a seu destino.

\section{Porto Maravilha}

Nas últimas décadas, o modelo da cidade de assentamentos de luxo distantes do centro levado ao paroxismo na ocupação da Barra da Tijuca vai apresentando sinais claros de esgotamento. O número de automóveis se multiplica, as autopistas se congestionam e mesmo o espaço social homogêneo e seguro idealizado vai apresentando fraturas diversas, na medida em que sinais de alguma mobilidade social aparecem 
no país democrático. É nesse contexto que vai se modificando a dinâmica do mercado imobiliário do Rio de Janeiro, através do aumento da procura de imóveis na região central, o que coloca em evidência o potencial de reintegrar a zona portuária como espaço de moradia e prestação de serviços a grupos sociais mais abastados (Andreatta; Herce, 2011). Esse novo interesse dos incorporadores imobiliários pela área portuária é condição necessária para o modelo de reforma urbana compreendido no projeto Porto Maravilha, criado em 2009.

Primeiramente, o projeto segue uma tendência global da acumulação financeira por despossessão, a saber, a utilização de megaeventos esportivos como vetores da reestruturação do espaço urbano para a criação de valor. Note-se que o Rio de Janeiro foi escolhido para ser a sede das Olimpíadas de 2016 no mesmo ano de 2009. Diversas pesquisas têm apontado a importância desses megaeventos para incluir as cidades nos novos fluxos financeiros (Burbank, Andranovich e Heying, 2001; Gaffney, 2010; Roche, 2000; Soares, 2013; Whitson; Horne, 2006). Sua realização tornou-se a justificativa para impulsionar uma série de programas e obras capazes de reestruturar urbanisticamente as cidades-sedes, de modo a potencializar o turismo de massa internacional, abrir um novo ciclo de edificações e de valorização do solo e atrair investimentos imobiliários. Como afirma Gaffney (2010, p.27), os megaeventos impõem uma "doutrina de choque neoliberal" para acelerar a mercantilização das cidades. Além disso, uma das principais consequências dos megaeventos esportivos tem sido, como destaca Soares (2013:200), a revitalização de antigas centralidades que se encontravam desvalorizadas, como é o caso do porto do Rio.

Harvey (2002:104) mostra que esse padrão de acumulação vem seguindo o exemplo de Barcelona, quando os Jogos Olímpicos de 1992 propiciaram grandes oportunidades para a acumulação de rendas monopolistas. Tal acumulação se apropriou do capital simbólico e cultural catalão para "vender" a imagem e as áreas da cidade no mercado mundial. Isso proporcionou uma transformação da arquitetura, da malha urbana central, do comércio local com a abertura de grandes empreendimentos (museus, centros de espetáculo etc.). Esse processo foi marcado por diversas contradições. Se é verdade que a "atração irresistível" da cultura catalã "trouxe em sua esteira a mercantilização multinacional homogeneizadora", não é menos certo que as reformas de Barcelona levaram à remoção da população pobre, apropriação de áreas públicas, eliminação do comércio local etc. (2002:104-105). 
Nessa mesma linha, a região portuária do Rio foi objeto de diversas remoções de antigos moradores, justificadas então pela necessidade de obras para as Olimpíadas (Rainha e Fonseca, 2013). Não apenas isso indica a relevância do papel da Olimpíada para essa nova etapa da acumulação na região portuária. O próprio prefeito Eduardo Paes declarou a importância dos jogos olímpicos para impulsionar o projeto Porto Maravilha - e isso, curiosamente, no momento em que ele decidiu retirar a zona portuária do roteiro das instalações olímpicas com a alegação de que, uma vez transformada em realidade, o projeto Porto Maravilha já aconteceria independentemente das Olimpíadas (O Globo, 2013). Tal decisão foi seguida, todavia, de um redirecionamento da região para se tornar o "Boulevard Olímpico", uma área que serviu de transmissões das competições, exposições e eventos musicais (Portal G1, 2015).

Para a execução do projeto Porto Maravilha, a Lei Municipal no 101/2009 estabeleceu a "Área de Especial Interesse Urbanístico" bem como a Companhia de Desenvolvimento Urbanístico da Região do Porto do Rio de Janeiro (CDURP), empresa mista com participação majoritária da Prefeitura do Rio de Janeiro, responsável por gerir os recursos financeiros do projeto e articular a relação entre os órgãos públicos e a Concessionária Porto Rio, formada pelas empreiteiras privadas que executam as obras e prestam serviços (Andreatta e Herce, 2011).

O financiamento das obras de infraestrutura e a própria construção de edificações no local seguem uma engenhosa parceria público-privada envolvendo a emissão de Certificados de Potencial Adicional de Construção (Cepacs). Trata-se de um sistema de captação de recursos contingenciados, isto é, a prefeitura só pode aplicar os recursos captados nas obras previstas na região portuária. Em contrapartida, os compradores dos títulos adquirem "o direito de construir além dos limites normais em áreas que receberão ampliação da infraestrutura urbana" (BM\&FBovespa, 2015).

Os Cepacs foram comprados por R \$ 3,5 bilhões em leilão de lote único e indivisível pelo Fundo de Investimento Imobiliário Porto Maravilha (FIIPM), vinculado ao Fundo de Garantia do Tempo de Serviço (FGTS) e administrado pela Caixa Econômica Federal. O FIIPM tem por obrigação pagar as despesas da Parceria Público-Privada e, ao mesmo tempo, restituir os valores do FGTS com as expectativas de valorização e negociação dos Cepacs. Nesse sentido, a dinâmica do 
projeto Porto Maravilha confirma uma das tendências do capitalismo financeiro, qual seja, a utilização de provisões e garantias dos trabalhadores para fins especulativos.

O processo de implementação do projeto e as negociações com a população local vêm impondo ajustes importantes ao plano, sobretudo no que diz respeito à tensão entre reforma urbana e preservação do patrimônio arquitetônico, arqueológico e da própria produção cultural que tem lugar na região. Conforme Vassallo (2015:65), o primeiro momento de implementação do projeto seguiu claramente um discurso apoiado em 'termos como 'vazio', 'isolamento' e 'degradação', o que justificaria a sua revitalização e modernização". A criação de dois grandes museus - o MAR, Museu de Arte do Rio de Janeiro, e o Museu do Amanhã - ambos desvinculados das manifestações culturais existentes na região, indicam, de algum modo, o desejo de reformar e preencher, também do ponto de vista da produção de sentidos, o espaço "vazio" e "degradado" representado pela zona portuária.

Ainda que o discurso do espaço degradado não tenha desaparecido, conforme mostra a citação do então prefeito Eduardo Paes, incluída na introdução do presente artigo, as audiências públicas e os embates com a população local, além das escavações arqueológicas que indicaram a existência do já analisado cemitério dos pretos novos, evidenciam as lacunas no discurso do vazio e do isolamento. Assim, os produtores culturais locais (músicos, artesãos etc.) foram sendo gradativamente incluídos nos projetos culturais a serem desenvolvidos na área do porto conforme previsto na mesma lei de 2009 que estabelece as diretrizes do projeto.

As formas de acumulação entrelaçada que têm lugar na zona portuária no âmbito do Projeto Porto Maravilha são múltiplas. Residualmente, persistem mecanismos de acumulação por mera espoliação, particularmente no caso dos moradores que ocupam imóveis sem a adequada regularização da propriedade legal:

As ocupações Zumbi dos Palmares, Flor do Asfalto e Machado de Assis foram desalojadas devido ao Projeto Urbano Porto Maravilha, projeto de "revitalização" da área portuária do Rio de Janeiro cuja concretização pressupõe a substituição da camada pobre residente por camadas mais adequadas aos objetivos econômicos e urbanos hegemônicos. (Assumpção e Schramm, 2013:97-98) 
A forma de acumulação, contudo, mais evidente é aquela que, conforme se descreveu acima, é própria ao capitalismo financeirizado e que implica a associação entre Estado, direito e capital financeiro para a criação de novos espaços de acumulação. O movimento observado aqui é duplo.

Primeiro, no plano discursivo-simbólico e da própria dinâmica urbana, constrói-se uma área geograficamente central, mas periférica do ponto de vista da acumulação, como um vazio demográfico, isolado da cidade capitalista. Ao mesmo tempo, a ocupação capitalista deste exterior desintegrado da acumulação, exige investimentos de infraestrutura a serem realizados com recursos captados de investidores que serão exatamente os únicos que poderão se apropriar do novo valor criado no espaço a ser reocupado. Os Cepacs são a materialização deste movimento duplo da acumulação entrelaçada, na medida em que eles permitem que o Estado remodele o espaço não capitalista para integrá-lo ao processo de acumulação e, simultaneamente, garantem o monopólio de exploração do novo espaço de acumulação a um seleto grupo previamente definido de investidores.

A cultura desempenha um papel ambivalente neste processo. De um lado, os museus criados na região e a ênfase na "diversidade cultural e arquitetônica" e na "valorização e resgate do patrimônio" (CDURP) buscam incrementar o valor do espaço que está sendo, simbólica e fisicamente, recriado:

O Porto Maravilha segue assim a tendência de projetos de revitalização em diversos países que buscam atrair um público de classes média e superior e desenvolver o turismo em bairros até então operários. (Vassallo, 2015:67)

Ao mesmo tempo, contudo, a ênfase à cultura, numa região marcada por uma longa história de produção cultural independente, conforma um espaço político para resistir ao esforço de mera instrumentalização das manifestações culturais locais como forma de agregar valor simbólico ao novo território de acumulação de capital. Isto é, a estilização dos movimentos culturais locais como territórios da autenticidade e da tradição ainda não penetrados pela acumulação capitalista cria possibilidades para articulação de sujeitos que resistem à incorporação de sua produção como mecanismos de valorização de um capital que não lhes pertencem. Pelo que pode ser depreendido do trabalho de Vassallo (2015), os embates entre os movimentos de resistência cultural e a parceria público-privada 
em favor da acumulação entrelaçada não têm ainda um ganhador claro. Tanto é possível que os produtores culturais mantenham a autonomia da produção e comercialização dos bens culturais que produzem, quanto é possível que sejam plenamente incorporados ao Porto Maravilha como simples prestadores de serviços a empreendimentos imobiliários e de lazer que vão dominando os novos espaços de acumulação capitalista criados na zona portuária do Rio de Janeiro.

\section{CONCLUSÕES}

A zona portuária do Rio de Janeiro representa uma espécie de espaço-síntese no interior do qual as diversas fases do capitalismo no Brasil e as formas variadas de integração da economia brasileira à economia mundial aparecem refletidas e materializadas. Criado ainda no século XVI, o porto permite, primeiro, o escoamento do açúcar e depois do ouro e a entrada de bens manufaturados e de um contingente de mais de um milhão de africanas e africanos raptados, escravizados e comercializados.

O porto não funcionava apenas como porta de entrada e saída de mercadorias e pessoas. O espaço do porto serviu também como cemitério de africanas e africanos recém-chegados ao Brasil, mercado de escravos e lugar da prestação de serviços variados.

O espaço adjacente ao porto, a zona portuária, vai mudando suas funções no curso da acumulação capitalista. Num primeiro momento, esse espaço concentra atividades essenciais para integrar a economia colonial ao capitalismo mundial. Paulatinamente, o entorno do porto vai sendo visto como lugar degradado no âmbito da cidade que cresce e se adensa em áreas afastadas. A ocupação das adjacências do porto vai se dando, cada vez mais, por população pobre, negros alforriados e depois libertos além de migrantes pobres de outras regiões do país etc. A zona portuária chega à segunda metade do século XX com uma reputação ambivalente. De um lado, é tratada como espaço urbano precário e degradado, desconectado da acumulação capitalista. De outro, se reconhece a vitalidade da produção cultural ali desenvolvida. O projeto Porto Maravilha representa um esforço articulado de incorporar esse território, central mas integrado de forma débil à produção de valor, à dinâmica da acumulação capitalista. 
A trajetória do porto, em seus quatro séculos de história, corporifica as dinâmicas da acumulação capitalista entrelaçada nos termos descritos acima. Antes de mais nada os fluxos de entrada e saída de pessoas e mercadorias indicam as interconexões entre a acumulação capitalista local e global iniciada, na época colonial, com a exportação de açúcar e o tráfico de pessoas escravizadas. Juntam-se a esses fluxos, mais tarde, a exportação de ouro, café e a importação de produtos manufaturados. Quando o porto, já no século XX, perde sua importância como corredor de entrada e saída de mercadorias e pessoas, os vínculos entre a acumulação local e global se esgarçam, só sendo retomados no século XXI, quando o Projeto Porto Maravilha busca reintegrar o espaço físico portuário às rotas do turismo mundial e aos canais pelos quais circulam o capital financeiro global.

Viu-se também que os diferentes padrões históricos de incorporar espaços não capitalistas ao processo de acumulação convivem nas diferentes fases. Assim, por exemplo, a primeira ordem legal de 1618, provavelmente a primeira parceira público-privada da história brasileira, inviabilizou o trabalho autônomo e assentou o trabalho escravo na prestação de serviços portuários. O monopólio da prestação destes serviços foi entregue a um concessionário, proprietário de escravos. Na medida em que os serviços portuários se prestavam à exportação de produtos coloniais, cujo excedente incorporado era apropriado na metrópole e no âmbito dos fluxos comerciais entre esta e outros países europeus, a acumulação viabilizada pelo porto reforçava o desacoplamento, descrito por Luxemburgo, entre os espaços de produção e consumo. Além disso, parcerias público-privadas, seguindo o padrão de acumulação por despossessão, como descrito por Harvey, e a Landnahme, descrita por Dörre, acompanham toda a história do porto, como se dá com a concessão do Lazareto em 1810 e culminando, recentemente, com o Projeto Porto Maravilha.

A história do porto representa também uma grande continuidade no que diz respeito à combinação de políticas públicas, instrumentos jurídicos e a mobilização da cultura e de recursos discursivos como forma de incorporar espaços não capitalistas ao processo de acumulação. O Estado e o direito se prestaram, desde o século XVII, através de obras públicas e dos regimes de concessão e de propriedade privada, a garantir a apropriação de excedentes com serviços portuários e adjacentes. Pelos mesmos mecanismos, mas também por medidas sanitaristas, o Estado e o direito configuraram as dinâmicas de integração 
da zona portuária como espaço de acumulação do capital imobiliário. De forma similar, ambos também contribuíram, em outros momentos, para desmercantilizar o solo da zona portuária, através da construção de vias de circulação que degradam o espaço local e investimentos em outras áreas da cidade, deslocando, assim, os interesses do mercado imobiliário para essas regiões. Vale-se também do recurso ao discurso do vazio e das áreas degradadas, em todos os períodos históricos, para desvalorizar a área, de sorte a permitir, num momento posterior, sua incorporação à acumulação com custos baixos.

A cultura funciona ao menos desde o final do século XIX de maneira dupla. Naquela ocasião, as manifestações culturais afro-brasileiras concentradas na zona portuária foram usadas como expressão da deterioração moral da área e pretexto para a intervenção sanitarista e disciplinadora do Estado. No contexto contemporâneo, as mesmas manifestações servem como argumento publicitário para estimular a integração da área ao mercado imobiliário financeirizado.

Por fim, no que diz respeito ao entrelaçamento entre as categorizações sociais, fica evidente que a integração do espaço não capitalista da colônia à dinâmica global da acumulação é concomitante com a construção do conceito de raça e com escravização de pessoas negras capturadas na África. O porto funcionava ao mesmo tempo como porta de entrada de negros escravizados e como espaço de transformação da vida humana do escravizado em mercadoria, na medida em que era ali que os africanos raptados eram reduzidos à condição de escravos, sendo classificados, expostos e comercializados. Após a proibição do tráfico de africanos escravizados e, finalmente, com a abolição da escravidão em 1888, uma pequena parte dos ex-escravos é incorporada aos serviços portuários como classe de trabalhadores assalariados. Boa parte não é integrada ao mercado de trabalho ou só é muito precariamente e encontra nos arredores do porto solo desvalorizado no qual busca se assentar.

(Recebido para publicação em 15 de fevereiro de 2016)

(Reapresentado em 8 de abril de 2019)

(Aprovado para publicação em 23 de março de 2019) 


\section{NOTAS}

1. Esta e todas as citações de obras publicadas em alemão, espanhol e inglês foram traduzidas aproximativamente pelos autores deste artigo para o português.

2. Landnahme significa, numa tradução literal, tomada de terras. No sentido que Dörre atribui ao termo, contudo, terra se refere, de maneira geral, a qualquer meio usado na produção de valor. Para não perder de vista esse sentido mais geral aplicado ao termo, ele será utilizado, ao longo do presente texto, na forma original em alemão.

3. Por esse motivo, Harvey (2005:147) dentro de seu aparato conceitual considera a financeirização e a privatização formas contemporâneas de acumulação por despossessão.

4. Sobre a relação entre a acumulação primitiva e o colonialismo, Marx (2013:779) afirma: "A descoberta de terras com ouro e prata na América, a dizimação, escravização e soterramento da população nativa nas minas, a exploração inicial e o saqueamento das Índias Ocidentais, a transformação da África numa área comercial de caça aos de pele negra caracterizam a aurora da era capitalista de produção. Estes processos idílicos são elementos principais da acumulação primitiva". A expressão idílicos é usada por Marx aqui de forma irônica para criticar o elogio liberal do capitalismo.

5. Já nos primeiros anos do século XVIII, circulavam pelo porto do Rio de Janeiro uma quantidade significativa de riquezas despertando a cobiça internacional. Assim, o pirata francês Duguay-Trouin comandando uma esquadra de 18 embarcações e 5.000 homens desencadeia campanha "financiada por diferentes armadores e acionistas franceses" (Figueiredo, 2005:44) invadindo e ocupando a cidade do Rio de Janeiro por 50 dias em 1711. O pirata só deixa a cidade depois de receber um monumental resgate (cf. Soares e Moreira, 2007:104; Honorato, 2008:31; Moura, 1995:64; Tavares, 2012:48).

6. Valongo é a denominação de um dos sacos que formavam a região portuária e que, posteriormente, junto ao trecho da orla imediatamente anterior (Valonguinho) passou a designar o bairro de mesmo nome (hoje, a Saúde e a Gamboa). Historicamente, ela é tratada como equivalente à região portuária. Adotaremos aqui igualmente essa denominação.

7. Neste sentido, o intento da Associação Comercial de modificar as formas de ocupação da área se insere no âmbito de outras propostas que, entre os anos 1970 e 1980, frustraram, conforme Andreatta e Herce (2011), porque "foram todas propostas pouco realistas, à medida que não contavam com acordos prévios nem com o proprietário do porto (o governo federal) nem com o operador-concessionário (Docas-Rio)".

8. A expressão era utilizada para distingui-los dos escravos indígenas, também existentes na época.

9. "Atravessadores" eram pequenos comerciantes que compravam escravos recém-chegados antes dos senhores de engenho e os revendiam a eles, aproveitando-se do tempo que tais senhores empregavam para chegarem no Rio de Janeiro, por morarem longe (Honorato, 2008:65).

10. A partir de relatos de viajantes, Honorato (2008:83) calcula que, em 1826, cada uma das "casas" continha cerca de 2.000 escravos para a venda. Além disso, como mostra Pereira (2007:76), toda a região se encontrava tomada por casas de comércio, de importação 


\section{Guilherme Leite Gonçalves e Sérgio Costa}

e exportação, depósitos de armadores e trapiches. Havia um movimento constante de navios.

11. Ver AHU-RJ, cód. 225 (apud. Honorato 2008:73).

12. O Lazareto era o lugar no qual todos os africanos e africanas doentes chegados no porto do Rio deveriam ser deixados em quarentena.

13. Eram eles: João Gomes Valle, José Luiz Alves, e João Álvares de Souza Guimarães e Companhia (Honorato, 2008:105; Pereira, 2007:106)

14. No que se refere a essa decadência, cabe destacar também o papel do crescimento da cidade em direção à Barra da Tijuca, no oeste da cidade, depois dos anos 1970. Como bem mostra Moreira (2004:82), na idealização de seus planejadores: “O novo bairro seria um novo centro, capaz de oferecer alta qualidade de vida a seus habitantes, o que, para os ideais da época, significava vista livre, insolação, aeração, fácil circulação e especialização de funções, além de segurança, infraestrutura, comércio e serviços". 


\section{REFERÊNCIAS}

ABRATEC (Associação Brasileira dos Terminais de Contêineres). "Estatísticas". Disponível em: http:/ / www.abratec-terminais.org.br/estatisticas. Acessado em 08/02/2016.

ANDREATTA, Verena; HERCE V., Manuel. (2011), “Y Las Olimpíadas de 2016, La revitalizacion del centro urbano sobre la conjugación de los proyectos 'Porto Maravilha' y ‘Porto Olímpico'”. Cuaderno Urbano, v. 10, n. 10, pp. 127-155.

ASSUMPÇÃO, Erik; SCHRAMM, Fermin R. (2013), "Bioética e habitação: leitura ética sobre as ocupações urbanas no centro do Rio de Janeiro". Revista Bioética, v. 1, n. 21, pp. 96-105.

AZEVEDO, André. (2003), “A reforma Pereira Passos: uma tentativa de integração urbana". Revista Rio de Janeiro, n. 10, pp. 33-79.

BIRD, James. (1957), The Geography of the Port of London. London: Hutchinson University Library.

BACKHOUSE, Maria. (2015), Grüne Landnahme - Palmölexpansion und Landkonflikte in Amazonien. Münster: WestfälischesDampfboot.

BENCHIMOL, Jaime L. (1992), Pereira Passos: um Haussmann tropical. Rio de Janeiro: Prefeitura da Cidade do Rio de Janeiro.

BICALHO, Maria Fernanda. (2007), O Rio de Janeiro: uma capital entre dois impérios. Rio de Janeiro: Arquivo Geral da Cidade do Rio de Janeiro.

BM\&FBOVERSPA. “Certificado de Potencial Adicional de Construção”. Disponível em: http:/ / www.bmfbovespa.com.br/pt-br/mercados/fundos/cepacs/cepacs.aspx?idioma=pt-br . Acessado em 08/02/2016.

BOYER, Robert; SAILLARD, Yves (orgs.). (2005), Regulation Theory: The State of the Art. London: Routledge.

BURBANK, Matthew; ANDRANOVICH, Gregory; HEYING, Charles. (2001), Olympic dreams: the impact of mega-events on local politics. London: Lynne Rienner.

CARDOSO, Elizabeth Dezouzart et al. (1987), Saúde, Gamboa, Santo Cristo. Rio de Janeiro: Index.

CARDOSO R. (2015) "Do Valongo à favela: A primeira periferia do Brasil". In Diniz C e Cardoso R. (org.) Do Valongo à favela: Imaginário e Periferia. Rio de Janeiro: Instituto Odeon, pp. 12-37 (edição bilíngue).

CARVALHO, José Murilo de. (2007), "Prefácio". À flor da terra : o cemitério dos pretos novos no Rio de Janeiro. Rio de Janeiro: IPHAN.

CDURP (Companhia de Desenvolvimento Urbanístico da Região do Porto do Rio de Janeiro). (s.d.), Porto Maravilha Cultural. Rio de Janeiro: Companhia de Desenvolvimento Urbano da Região do Porto do Rio, prospecto.

COUPER, Alastair. (1972), The geography of sea transport. London: Hutchinson.

DARWIN, Charles. (1959 [1913]), The Voyage of the Beagle. Tadworth: The Press of Kingswood. 


\section{Guilherme Leite Gonçalves e Sérgio Costa}

DA SILVA, Daniel Afonso. (2012), O enigma da capital: a mudança do vice-reinado para o Rio de Janeiro em 1763. (Tese de Doutorado) Universidade de São Paulo, São Paulo.

DÖRRE, Klaus. (2012), “Die neue Landnahme. Dynamiken und Grenzen des Finanzmarktkapitalismus". In K. Dörre; S. Lessenich; H. Rosa (eds.), Soziologie Kapitalismus - Kritik: eine Debatte. Frankfurt: Suhrkamp.

DUCRUET, César. (2005), “Dynamiques scalaires et temporelles des villes-ports : typologie mondiale de 330 trajectoires urbano-portuaires, 1990-2000". Actes des Rencontres de Théo Quant. Besançon: Université de Franche-Comté.

FIGUEIREDO, Claudio. (2005), O Porto e a Cidade. O Rio de Janeiro entre 1965 e 1910. Rio de Janeiro: Casa da Palavra.

PORTAL G1. (2015), "Rio terá Boulevard Olímpico com eventos e transmissões de jogos". Disponível em: http://g1.globo.com/rio-de-janeiro/noticia/2015/06/rio-tera-boulevard-olimpico-com-eventos-e-transmissoes-dos-jogos.html . Acessado em 12/02/2016.

GAFFNEY, Christopher. (2010), "Mega-events and Socio-spatial Dynamics in Rio de Janeiro, 1919-2016". Journal of Latin American Geography. v. 1, n. 9, pp. 7-29.

HARVEY, David. (1975), "The geography of capitalist accumulation: a reconstruction of the Marxian Theory". Antipode. v. 2, n. 7, pp. 9-21.

. (1985), "The geopolitics of capitalism". In D. Gregory; J. Urry (eds.), Social Relations and Spatial Structure. London: Macmillan, pp. 128-63.

(1989), "From managerialism to entrepreneurialism: the transformation in urban governance in late capitalism". Geografiska Annaler. v. 1, n. 71. , pp. 3-17.

. (2002), "The art of rent: globalization, monopoly and the commodification of culture". Socialist Register. n. 38, pp. 93-110.

. (2004), “The 'new' imperialism: accumulation by dispossession". Socialist Register, n. 40, pp. $63-87$.

. (2005), Der neue Imperialismus. Hamburg: VSA-Verl.

HAAG, Carlos. (2011), “Os ossos que falam”. Revista Pesquisa FAPESP, n. 190, pp. 24-29.

HILF, Sebastian. (2012), Unternehmerische Stadtpolitik in Rio de Janeiro - untersucht am Beispiel des Hafenrevitalisierungsprojekts Porto Maravilha. Mag.rer.nat., Wien: Universität Wien.

HILLING, David. (1988) "Socio-economic change in the Maritime Quarter: the demise of Sailortown". In M. S. Husain; D. Pinder; B. S. Hoyle (eds.), Revitalising the Waterfront: International Dimensions of Dockland Redevelopment. London: Belhaven Press.

HONORATO, Claudio de Paula. (2008), Valongo: o mercado de escravos do Rio de Janeiro, 17581831. (Dissertação de Mestrado). Universidade Federal Fluminense, Rio de Janeiro.

. (2006), Controle sanitário dos negros novos no Valongo. Rio de Janeiro: XII Encontro Regional de História (ANPUH-RJ).

INNIS, Harold. (1956), Essays in Canadian Economic History. Toronto: University of Toronto Press. 
LAMARÃO, Sergio Tadeu de Niemeyer. (2006), Dos Trapiches ao porto: um estudo sobre a área portuária do Rio de Janeiro. Rio de Janeiro: Secretaria Municipal das Culturas.

LUXEMBURG, Rosa. (1975)[1913], “Die Akkumulation des Kapitals". Gesammelte Werke, Rosa Luxemburg. v. 5. Berlin: Institut für Marxismus-Leninismus.

MARX, Karl. (2013)[1867], “Das Kapital: Kritik der politischen Oekonomie”. Marx Engels Werke, v. 1, Berlin: Dietz.

. (1983)[1894], “Das Kapital: Kritik der politischen Oekonomie". Marx Engels Werke, v. 3, Berlin: Dietz.

MELLO, Fernando Fernandes de. (2003), A Zona Portuária do Rio de Janeiro: antecedentes e perspectivas. (Dissertação de Mestrado). Instituto de Pesquisa e Planejamento Urbano e Regional da Universidade Federal do Rio de Janeiro. Rio de Janeiro.

MOREIRA, Clarissa C. (2004), A cidade contemporânea entre a tábula rasa e a preservação. São Paulo: UNESP.

MOURA, Roberto. (1995), Tia Ciata e a Pequena África no Rio de Janeiro. Rio de Janeiro: Secretária Municipal de Cultura.

NORCLIFFE, Glen; BASSET, Keith; HOARE, Tony. (1996), “The emergence of post modernism on the urban water front. Geographical perspectives on changing relationships". Journal of Transport Geography, v. 2, n. 4, pp. 123-134.

O GLOBO. (2013), "Paes quer que árbitros e jornalistas fiquem na Barra nos Jogos de 2016". Disponível em: http://oglobo.globo.com/rio/paes-quer-que-arbitros-jornalistas-fiquem-na-barra-nos-jogos-de-2016-11877405. Acessado em 12/02/2016.

PAES, Eduardo. (2015), "De volta ao centro". Revista Porto Maravilha, n. 18, p. 3.

PEREIRA, Júlio Cesar Medeiros da Silva. (2007), À flor da terra: o cemitério dos pretos novos no Rio de Janeiro. Rio de Janeiro: IPHAN.

. (2013), "Revisitando o Valongo: mercado de almas, lazareto e cemitério de africanos no portal do Atlântico (a cidade do Rio de Janeiro, no século XIX). Revista de História Comparada, v. 1, n. 7, pp. 218-243.

PINHEIRO, Augusto I. F.; RABHA, Nina M. C. E. (2004), Porto do rio de janeiro: construindo a modernidade. Rio de Janeiro: Andrea Jacobsson Estúdio.

RAINHA, Felippe Andrade; FONSECA, Priscilla Rodrigues. (2013), Morro da Providência e Porto Maravilha: caminhando entre a realidade e a ilegalidade jurídica. Trabalho apresentado no XV Encontro da Associação Nacional de Pós-Graduação e Pesquisa em Planejamento Urbano e Regional. Recife, 20-24 de maio.

ROCHE, Maurice. (2000), Mega-events and modernity: olympics and expos in the growth of global culture. New York: Routledge.

SANTOS, Francisco Agenor de Noronha. (1995), As freguesias do Rio antigo vistas por Noronha Santos. Rio de Janeiro: O Cruzeiro.

SOARES, Eliana Miranda Araujo da Silva; MOREIRA, Fernando Diniz. (2007), “Preservação do patrimônio cultural e reabilitação urbana: o caso da zona portuária da cidade do Rio de Janeiro". Da Vinci, v. 1, n. 4, pp. 101-20. 


\section{Guilherme Leite Gonçalves e Sérgio Costa}

SOARES, Paulo Roberto Rodrigues. (2013), “Megaeventos esportivos e o urbano: a copa do mundo de 2014 e seus impactos nas cidades brasileiras". Revista FSA, n. 10, pp. 195-214.

TAVARES, Reinaldo Bernardes. (2012), Cemitério dos Pretos Novos, Rio de Janeiro, século XIX: uma tentativa de delimitação espacial. (Dissertação de Mestrado), Museu Nacional, Rio de Janeiro.

VASSALLO, Simone. (2015), "Culturas em disputa: a criação do programa Porto Maravilha Cultural no projeto de revitalização da região portuária do Rio de Janeiro". In: G. Pontes Jr.; M. B. de Castro; M. S. dos Santos (orgs.), Diálogos interdisciplinares. Literatura e políticas culturais. Rio de Janeiro: Ed. UERJ, pp. 57-82.

WITHERICK, Michael. (1981), "Port developments, port-city linkages and prospects for maritime industry: a case study of Southampton". Cityport Industrialization and Regional Development. Oxford: Pergamon, pp. 113-132.

WHITSON, David; HORNE, John. (2006), "The Glocal Politics of Sports Mega-Events: Underestimated costs and overestimated benefits? Comparing the outcomes of sports mega-events in Canada and Japan". The Sociological Review, n. 54, pp. 71-89. 


\section{RESUMO \\ Valor Maravilha: Metamorfoses da Acumulação Capitalista no Espaço Portuário do Rio de Janeiro}

Diversos autores têm promovido uma renovação da teoria marxista da expansão capitalista por meio da retomada da noção de repetição da acumulação primitiva do capital. Tem-se a ideia de que o desenvolvimento do capitalismo sempre necessita recorrer a um "fora" não capitalista, isto é, precisa estender o processo de acumulação a espaços ainda não integrados às cadeias de produção de valor. Para isto, faz uso de violência explícita não econômica, como, por exemplo, a política colonial ou imperial, espoliações, leis sanguinárias etc. No presente artigo, estudamos as diferentes dimensões desse processo à luz da história da região portuária do Rio de Janeiro. Do ponto de vista teórico, isso possibilita repensar as categorias do debate citado a partir do conceito de acumulação entrelaçada, cunhado no artigo. Do ponto de vista empírico, sustentamos que a região portuária do Rio de Janeiro representa uma espécie de espaço-síntese, no interior do qual as diversas etapas históricas da acumulação capitalista aparecem materializadas na forma de um movimento de incorporação e desacoplamento de tal região aos processos de transformação do espaço socialmente construído em mercadoria.

Palavras-chave: acumulação primitiva; expansão do capitalismo; porto do Rio de Janeiro; escravidão

\section{ABSTRACT \\ "Wonder Value": Metamorphoses of Capitalist Accumulation in the Rio de Janeiro Port Region}

Several authors have promoted a renewal of the Marxist theory of capitalist expansion by bringing back the notion of repetition of primitive capital accumulation. The idea that the development of capitalism always needs to resort to a non-capitalist "exterior" is recurrent, that is, capitalism must extend the process of accumulation to spaces not yet integrated into the value production chains. In this process, it makes use of explicit non-economic violence, such as colonial or imperial politics, spoliation, bloodthirsty laws, etc. In the present article, we study the different dimensions of this process in light of the history of the port region of Rio de Janeiro. From the theoretical point of view, this makes it possible to rethink the categories of this debate starting from the concept of intertwined accumulation, coined in the article. From the empirical point of view, we argue that the Rio de Janeiro port region represents a kind of synthesis space, within 
which the various historical stages of capitalist accumulation appear materialized in the form of a movement of incorporation and decoupling of such region into the processes of transforming socially constructed spaces into commodities.

Keywords: accumulation; expansion of capitalism; port of Rio de Janeiro; slavery

\section{RÉSUMÉ}

Valeur Miracle: métamorphoses de l'accumulation capitaliste dans l'espace portuaire de Rio de Janeiro

Plusieurs auteurs ont favorisé un renouvellement de la théorie marxiste de l'expansion capitaliste en reprenant la notion de répétition de l'accumulation primitive du capital. On a l'idée que le développement du capitalisme doit toujours recourir à un «extérieur» non capitaliste, c'est-à-dire qu'il doit étendre le processus d'accumulation à des espaces non encore intégrés dans les chaînes de production de valeur. Pour cela, il utilise des violences non économiques explicites, telles que la politique coloniale ou impériale, la spoliation, les lois assoiffées de sang, etc. Dans le présent article, nous étudions les différentes dimensions de ce processus à la lumière de l'histoire de la région portuaire de Rio de Janeiro. D’un point de vue théorique, cela permet de repenser les catégories de débat citées à partir du concept d'accumulation entrelacée, forgé dans l'article. D'un point de vue empirique, nous soutenons que la région portuaire de Rio de Janeiro représente une sorte d'espace de synthèse, au sein duquel les différentes étapes historiques de l'accumulation capitaliste se matérialisent sous la forme d'un mouvement d'incorporation et de découplage de cette région dans les processus de transformation de l'espace socialement construit en marchandise.

Mots-clés: accumulation primitive; expansion du capitalisme; port de Rio de Janeiro; l'esclavage

\section{RESUMEN}

Valor Maravilla: Metamorfosis de la Acumulación Capitalista en el Espacio Portuario de Rio de Janeiro

Diversos autores han promovido una renovación de la teoría marxista sobre la expansión capitalista por medio de la recuperación de la noción de repetición de la acumulación primitiva del capital. Se tiene la idea de que el desarrollo del capitalismo siempre necesita recurrir a un "afuera" no capitalista, es decir, que necesita extender el proceso de acumulación a espacios todavía no integrados a las cadenas de producción de valor. Para esto, se hace uso de la violencia explícita 
no económica como, por ejemplo, la política colonial o imperial, despojos, leyes sangrientas etc. En el presente artículo, estudiamos las diferentes dimensiones de ese proceso a la luz de la historia de la región portuaria de Rio de Janeiro. Desde el punto de vista teórico, eso posibilita repensar las categorías del debate citado a partir del concepto de acumulación entrelazada, acuñado en el artículo. Desde el punto de vista empírico, sustentamos que la región portuaria de Rio de Janeiro representa una especie de espacio de síntesis, al interior del cual las diversas etapas históricas de la acumulación capitalista aparecen materializadas en la forma de un movimiento de incorporación y desacoplamiento de tal región a los procesos de transformación del espacio socialmente construido en mercancía.

Palabras clave: acumulación primitiva; expansión del capitalismo; puerto de Rio de Janeiro; esclavitud 